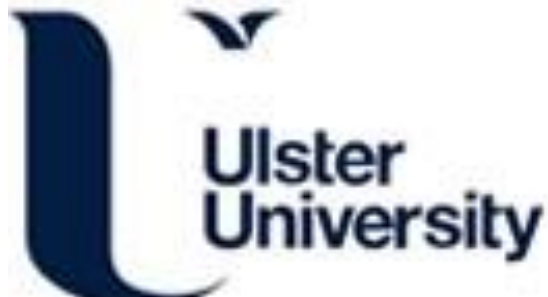

\section{Future-proofing the Success of Food Festivals through Determining the Drivers of Change: A Case Study of Wellington on a Plate}

Yeoman, I., McMahon-Beattie, U., Findlay, K., Goh, S., Tieng, S., \& Nhem, S. (2021). Future-proofing the

Success of Food Festivals through Determining the Drivers of Change: A Case Study of Wellington on a Plate. Tourism Analysis, 26(2-3), 167-193. https://doi.org/10.3727/108354221X16079839951457

Link to publication record in Ulster University Research Portal

\section{Published in:}

Tourism Analysis

Publication Status:

Published (in print/issue): 14/04/2021

DOI:

10.3727/108354221X16079839951457

\section{Document Version}

Publisher's PDF, also known as Version of record

\section{General rights}

Copyright for the publications made accessible via Ulster University's Research Portal is retained by the author(s) and / or other copyright owners and it is a condition of accessing these publications that users recognise and abide by the legal requirements associated with these rights.

\section{Take down policy}

The Research Portal is Ulster University's institutional repository that provides access to Ulster's research outputs. Every effort has been made to ensure that content in the Research Portal does not infringe any person's rights, or applicable UK laws. If you discover content in the Research Portal that you believe breaches copyright or violates any law, please contact pure-support@ulster.ac.uk. 


\title{
FUTURE PROOFING THE SUCCESS OF FOOD FESTIVALS THROUGH DETERMINING THE DRIVERS OF CHANGE: A CASE STUDY OF WELLINGTON ON A PLATE
}

\author{
IAN YEOMAN, ${ }^{*}$ UNA MCMAHON-BEATTIE, $\dagger$ KATHERINE FINDLAY, $\$$ SANDRA GOH,§ \\ SOPHEA TIENG, $₫$ AND SOCHEA NHEM\#
}

*School of Management, Victoria University of Wellington, Wellington, New Zealand $\dagger$ Department of Hospitality and Tourism Management, Ulster University, Belfast, UK \$Penrose, Auckland, New Zealand

$\S$ School of Hospitality and Tourism, Auckland University of Technology, Auckland, NZ ๆTourism Department, Saint Paul Institute, Sangkat Dangkor, Khan Dangkor, Cambodia \#Department of Tourism, Royal University of Phnom Penh, Phnom Penh, Cambodia

\begin{abstract}
In parallel with the growth and popularity of food tourism, the increase in food-specific events and festivals has been significant. Events have become an important element of the experience economy; often their economic and social benefits have been related to improvements in the quality of life for communities and regions. Food festivals provide an opportunity for event goers to socialize, as by their nature they bring people together. However, how do we future proof the success of such events? Adopting a practice theory position and a pragmatism paradigm, this article investigates the future of food festivals using a case study of Wellington on a Plate (WOAP), which is New Zealand's most successful food festival, operated by the Wellington Culinary Events Trust (WCET). In line with scenario planning research methods, 12 "remarkable persons" were interviewed to identify 22 megadrivers of change, including mobility, redefining luxury, technological immersion, social capital, social demography changes, and accessibility. Adapting Yeoman's conceptual framework of food tourism drivers for food festivals and linking to these megadrivers of change, a conceptual framework was derived that considers five factors of success: Food festivals as political capital; Food festivals as a visionary state; Sense of community; The drive for affluence and exclusivity; and Fluid identity and foodies. The development of this conceptual framework, which links success to the external environment, contributes to the future proofing of food festivals.
\end{abstract}

Key words: Food tourism; Futures studies; Festival; Pragmatism; Future proofing

Address correspondence to Ian Yeoman, Associate Professor, School of Management, Victoria University of Wellington, PO Box 600, Wellington 6035, New Zealand. E-mail: ian.yeoman@vuw.ac.nz 


\section{Introduction}

In parallel with the growth and popularity of food tourism, the emergence of food specific events and festivals has been exponential (Getz et al., 2014). In the USA alone, there are more than a thousand food and wine festivals held annually, such as The Food Network \& Cooking Channel South Beach Wine \& Food Festival (http://sobewff.org/) or the National Shrimp Festival (http://www.myshrimp fest.com/) or the more specialist or peculiar Spam Jam Festival (http://spamjamhawaii.com/) or Roadkill Festival (http://www.bbc.com/news/ world-us-canada-37501036). Events have become an important element of the experience economy; they are often related to improvements to quality of life for communities and regions through their economic and social benefits (Yeoman, McMahonBeattie, Fields, et al., 2015). Fundamentally, food festivals and events are a representation of how the experience economy is at the epicenter of the changing nature of the tourism product (Getz et al., 2014). Given their popularity and the increasingly competitive nature of the event industry, one might ask what a successful food festival is. How does a food festival relate to and operate in a changing external environment? For example, one might question how climate change will affect the food supply chain and what this will mean for food festivals, or how technological trends will influence food festivals. These are some of the many questions that arise when exploring the future of food festivals and events.

Indeed, looking to the future allows us to understand the changing nature of the tourism product. This entails understanding the drivers of change that create the tourism product and aligning these with the external environment to future proof and create successful food festivals (Wigford, 2014; Yeoman, McMahon-Beattaie, Backer, et al., 2014). In order to link success with the external environment, this article uses a case study of Visa Wellington on a Plate (WOAP), which is New Zealand's most successful food festival.

\section{Wellington on a Plate}

WOAP or Visa Wellington on a Plate (Visa WOAP), if you include the sponsor's name, began in 2009 with 43 participating restaurants and 30 events, and it sold approximately 400 tickets. (This is an estimate, as all venues sold their tickets individually and kept no central records.) In 2016, this had grown to 148 restaurants, 140 events, and 9,070 tickets (personal correspondence with S. Miekle, 2017). WOAP is an annual festival, held in the last two weeks of August, that showcases the best of Wellington's culinary and hospitality industry, with farm to plate events, special menu offerings (known as Dine Wellington), and industry activity. Events range from free public lectures to events for pets, competitions, cookery classes, night markets, a beer festival, and much more. Award winning events have included Rimutaka Prison Gate to Plate (https://www.visawoap.com/ rimutaka-prison-gate-to-plate-faqs) where celebrity chef Martin Bosley mentors prisoners to create a fine dining experience at the local prison (thereby taking on a social responsibility dimension), to Dine with Monet (https://www.qthotelsandresorts. com/wellington/qt-blog/dine-with-monet/), which is a dining experience based on the food featured in Monet's paintings. The focus of WOAP is on experiences for foodies, innovations, and excitement. Although most events are based in Wellington, they spread into the hinterland as far north as Kapiti and the Wairapa in the East. The festival has grown substantially since 2009 to become the hallmark event for food tourism in New Zealand. Getz et al. (2014) defined hallmark events as "major food-themed events held periodically, co-branded with the destination, strongly appealing to foodies and considered to be a permanent institution and valued tradition by residents" (pp. 153-154). The festival is organized by Wellington Culinary Events Trust (WCET) with Sarah Miekle as Chief Executive and Festival Director since inception. The trust is a not-for-profit organization that sets out to work across consumer, industry, and partner channels to showcase the very best of the Wellington culinary and hospitality community. Further details about WOAP and WCET can be found at https://www. visawoap.com/

\section{Research Brief}

As part of a wider scenario planning study, this research was driven by WCET's desire to 
understand and identify the megadrivers of change for food festivals globally (not just in Wellington and New Zealand). It was keen to understand the "big picture" and to explore the underlying influences that are driving food festivals in order to create a sustainable and successful future for WOAP. On a practical level, the research sought to identity a series of megadrivers of change that will shape the future of food festivals, to position and discuss WOAP within the context of these megadrivers, and to appraise the WOAP proposition as a successful food festival. Academically, the research aimed to develop a conceptual framework by building upon Yeoman, McMahon-Beattie, Fields, et al.'s (2015) model of food tourism futures to identify factors for success, thereby future proofing food festivals and events (Yeoman, McMahon-Beattier, Backer, et al., 2014).

\section{Food Tourism}

Food and tourism have been around since the beginning of time (Yeoman, McMahon-Beattie, Fields, et al., 2015). As Domenico (2001) stated:

It was the German Bishop Johnannes Fugger, in the 12 th century who was journeying to Rome, his servant travelled a few days ahead to select suitable places to stay at, eat and drink. The servant would chalk 'Est' (Latin for 'This is it') on the doors of places deemed suited to the bishop's taste. The inn in Montefiancone impressed the servant so much that he wrote 'Est! Est!! Est!!!' Legend has it that the bishop returned to Montefiascone on this way back from Rome to stay there for the rest of his life. (p. 123)

Indeed, given that destinations generally provide visitors with food and drink, it is surprising that academic interest in food tourism is relatively recent. After all, food tourism refers to anything from street vendors to farmers' markets to highend restaurants. It ranges from local, to regional, to global, and blended ingredients and cuisines. Yunn et al. (2011) declared that only deliberate food tourists travel specifically to seek out certain foods or ingredients. Opportunistic food tourists may look out for food and drink, whereas accidental food tourists participate in food and drink just because it is there, and they need it. Food tourism has been a visible research area for the past three decades, since Bélisle's (1983) exploration of the close relationship between food and tourism. However, more recent years (2008-2015) have witnessed its unprecedented growth and popularization in the tourism literature (Ellis et al., 2018).

As the food tourism literature began to develop, the field experienced a shift, that is, a "cultural turn" from those early management-focused studies to more holistic and exploratory discussions of food and culture (Everett \& Slocum, 2013). Not only did the frequency and volume of the studies significantly increase, but so did the variety of research approaches and concepts being explored (Ellis et al., 2018). The increased prominence of food tourism as a research topic has seen special editions of journals dedicated to the phenomenon. In 2015, the launch of the Journal of Gastronomy and Tourism meant the research topic had its own dedicated outlet for a community of academic researchers.

Ellis et al. (2018) argued that food tourism is:

about cultural anthropology through understanding the interactions of tourists with place through the medium of food. If food tourism is predominately about cultural anthropology, those in policy and business are managers of cultural resources from users, an image, sustainability, development and profit perspective. (p. 261)

Right at the center of this definition is the role of culture and its inseparability from authenticity and motivations that represent the origin, history, place, and language of a destination. The managers of food tourism are curators of this cultural anthropology, and food functions as the expression of identity and place (Ellis et al., 2018). Tourists interact with food through consumption and play, which become rituals, symbols, and forms of capital and distinction (Bourdieu, 2000; Sato et al., 2016; Sims, 2009, 2010). Food defines a place, as it is a representation of its history-for example, haggis and Scotland, Hangi and Maori (New Zealand), or pasta and Italy. However, food tourism is not a cultural museum; it is a tourism product that is indigested and experienced. The desire for new experiences is something living and interactive, with food tourists wanting to touch, see, listen, hear, and taste all things food (Laing \& Frost, 2015). Hence, the growing demand for everything from cooking classes, to craft beer, to food trails, and eating in three-star Michelin 
restaurants. Indeed, it is this focus on new experiences that stimulates the ever-growing demand for food festivals such the Melbourne Food and Wine Festival (http://www.melbournefoodandwine.com. $\mathrm{au} /$ ) or Hokitika Wild Food Festival (https://www. wildfoods.co.nz/).

\section{Food Festivals}

Within the food tourism literature, studies about food festivals have increased dramatically in the last decade (Kim, 2015). Research has investigated the motivational dimensions of tourists attending food festivals. Chang (2011), for example, examined the food experience at a festival and its relationship with tourist satisfaction and the perceived overall authenticity of the festival. Other studies have investigated visitors' perceptions of the healthiness and safety of the food served in festivals and fairs (Boo, 2000) and the relationship between visitors' satisfaction and behavioral intentions (Mason \& Paggiaro, 2012). Getz et al. (2014) noted that the motivations and behavior of foodies represent the predominate theme in food events research. For example, Lilleheim et al.'s (2005) study of the motives of suppliers and exhibitors at the Miami South Beach Food and Wine Festival concluded that fun and atmosphere are the most important attributes. Adding to this, Park et al.'s (2008) research highlighted that the desire for new experiences and tastes were the major motivations for foodies at food festivals, while Smith et al. (2010) concluded that food, novelty, and socializations where the main motivations. From another perspective, Modlik and Johnston's (2017) study of extreme foods used the notions of visceral pleasure (distaste) as hedonistic motivation. Most recently, Robinson et al.'s (2018) study of foodies and events is one of the first to use big data to understand segments via behaviors, motivations, and attitudes.

\section{The Future: Food Tourism and Festivals}

Getz et al. (2014) argued that a futures perspective is missing in the food tourism literature and that many discussions on the phenomena of food tourism and food festivals lack an understanding of the external environment and its potential impact. Yeoman, McMahon-Beattie, Fields, et al.'s (2015) edited book The Future of Food Tourism provides a comprehensive guide to this topic. It presents a systematic and pattern-based explanation of how the change could occur and the implications of that change for food tourism. The future is explored from a variety of perspectives and topics, from science to sustainable production to the people who produce the food. In the final chapter (Yeoman, McMahon-Beattie, \& Wheatley, 2015), an evaluation of the drivers of change is presented, based upon an analysis of the content of the contributing chapters. These drivers are identified for food tourism as political capital; food tourism as a visionary state; what it means to be a foodie; the drive for affluence and exclusivity; and fluid experiences in a postmodern world.

\section{What Is a Successful Festival?}

The festivals and events industry has one of the most competitive environments in the experience, tourism, and leisure economies (Yeoman, McMahon-Beattie, Backer, et al., 2014; Yeoman, Robertson, \& Smith, 2012). In such a competitive environment one might consider what success is and how can it be achieved. Existing literature on success factors tends to focus on the internal factors influencing the success of festival or events with limited exploration of the external environment and its implications. For example Bornhorst et al. (2010) determined that the key factors of success were economic performance, effective marketing initiatives, product and service offerings, quality of the visitor experience, and internal stakeholder relations. Measures of success should be focused on the most important factors of competition as determined by the visitors. Success has also been defined as the number of visitors - the more visitors the more income (Kinnunen \& Haahti, 2015). Many studies focus solely on economic success, and this is a result of the need to secure public sector funding (Andersson \& Getz, 2009; Myerscough, 1990; Yeoman, McMahon-Beattie, Backer, et al., 2014). Other studies have incorporated social, cultural, and environmental impacts as a definition of success (Fredline, 2003; Getz, 2002; Getz et al., 2010). Studies have also focused on the role of local communities and impacts (Lade \& Jackson, 2004). Indeed, Kinnunen and Haahti (2015) identified 
several common factors often mentioned in the literature, including sense of community, social interaction, variety of the program, atmosphere, experiences, event organizations, management of the event, information and marketing, brand equity, and cocreation. In the context of food festivals, one of the most cited studies by Einarsen and Mykletun (2009), who researched the success factors of Gladmatfestival in Stavanger, concluded that the festival's success was dependent on a strong cluster network of food and meal-producing institutions, organizations, and restaurants. The study adopted a driving forces model, but these drivers were akin to the critical success factors found in many other studies, rather than considering the external environment or focusing on megadrivers of change.

Many studies focus on indicators of success, that is, the conditions that determine what preconditions are likely to create the best or most successful outcome for the intended event or festival (Lemelin et al., 2015). These indicators have emerged from the general business literature and have been defined as the "limited number of areas in which satisfactory results will ensure successful competitive performance for the individuals, departments or organisations" (Bullen \& Rockart, 1986, p. 385). These indicators include management leadership, commitment and support, communications, employee relationships, technology, and many others (Butler, 1991). Another example of indicators is the research of Austin et al. (2006), which divided indicators into integrative drivers and implementing mechanisms. Maxim (2015) considered the term drivers of success that encompass the factors that have a positive influence on putting into practice policies that promote sustainable tourism development. These factors range from education to political will, strong community engagement, funding, long-term focus, and so on. The factors are primarily internal or business operations focused but do include some external political, economic, social, technological, environmental, and legislative (PESTEL) factors.

One important study of significance by Getz (2002) focused on why festivals fail. The research concluded that unsuccessful events occurred because of a lack of corporate sponsorships, the weather, overreliance on one source of money, inadequate marketing or promotion, and lack of strategic planning. The study of success is also well documented in the wider tourism literature; in particular, Bornhorst et al.'s (2010) comprehensive review of destination management organizations concluded that studies of success focused on marketing and the importance of stakeholders.

In summary, many studies investigating the success factors of festivals fail to evaluate the external environment, or the "outside," as Singh and Hsiung (2016) observe. What is missing is a systematic consideration of PESTEL factors. Understanding these is the essence of future proofing (Yeoman, McMahon-Beatter, Backer, et al., 2014).

\section{Drivers of Change}

Saritas and Smith (2011) noted that drivers of change are "those forces, factors and uncertainties that are accessible by stakeholders and create or drive change within one's business or institutional environment" (pp. 274-275). The use of a "drivers of change approach" is well documented in the futures and scenario planning literature (Luhmann, 1976; McDonald, 2011; van't Klooster \& van Asselt, 2006; van Zon, 1992). Drivers of change feature heavily because they are considered the building blocks for scenarios (Van der Heijden et al., 2002). Indeed, the two most important driving forces are often selected to shape a particular scenario in order to give a particular viewpoint or essence (Anindita, 2017; Postma \& Yeoman, 2016; Steiger, 2012; Sundbo, 2016). Megatrends or drivers are usually considered hierarchical drivers of change representing those driving forces that take a global perspective. They can be desirable or undesirable and can cause change with different degrees of pace and impact. They can also be progressive or in decline and can be hierarchical and orderly.

\section{Drivers and the Future of Tourism}

In 2050: Tomorrow's Tourism Yeoman (2012a) identified a series of megadrivers of change for the future of tourism. These megadrivers (clustered around, e.g., wealth, resources, and technology) are broken down further for the development of a variety of scenarios. For example, the chapter titled Edinburgh 2050: Technological Revolution illustrates a scenario of technological singularity (Kurzweil, 2005). In this scenario, the convergence of 
technology brings about a future in which humans and androids are indistinguishable in terms of their physical appearance, emotions, intelligence, and behavior. The drivers of change that bring about this imagined future include artificial intelligence, haptic technologies, and optical computing. Another chapter, Seoul 2050: The Future of Food Tourism, portrays a scenario where food is only for the elite in society. The drivers of change that bring about this scenario include climate change, wealth distribution, and the advancement of society. Indeed, numerous tourism studies have adopted a drivers of change approach to envisage the future (Ellis et al., 2018; Findlay \& Yeoman, 2015; Robertson et al., 2015; Schänzel \& Yeoman, 2014; Yeoman, 2012a; Yeoman, 2017; Yeoman, Brass, \& McMahon-Beattie, 2007; Yeoman, Lennon, et al., 2007; Yeoman \& McMahon-Beattie, 2015c; Yeoman, McMahon-Beattie, \& Findlay, 2014).

Theory and Practice: The Paradigm of Pragmatism

\section{Practice Theory}

Understanding the virtues of theory in an industry that is about practice is a conundrum (Leiper \& Hawker, 2004). Lewin (1951) has noted that "There's nothing so practical as a good theory" (p. 169). Feldman and Worline (2016) argued that the practicality of theory lies not in the conceptual labels and logics but in the questions it raises. In this context practice offers an explanation of "what is," "when is," and "how is,: whereas theory offers an explanation of "why is." Weick (1989) suggests that practicality comes from the way in which a theory shapes connections and how these new or unexpected connections enable the discovery of new implications for action. Sparrow (1998) argued that a focus on practice offers the opportunity to emphasize local action based on the particular knowledge of a context and to see how we create social worlds together in ways that enable new actions and new questions.

Management research is engaging increasingly with practice theories, drawing on these in areas as wide as information systems, strategy, leadership, and entrepreneurship (Jarzabkowski, 2005). While practice-theoretical studies share a commitment to understanding their various domains in terms of human activity, they developed relatively independently (Schatzki, 1996, 2001), and thus have established their own idiosyncratic agendas. These agendas entail different understandings of what constitutes a practice-theoretical approach and the distinctive advantages that can be derived from engaging with it. Tourism is a multidisciplinary field, and since it is vocational in nature, it is ripe for practice theory. Linking theory and practice in vocational industries is not new, especially in areas such as nursing and education. Notably, Dickoff et al. (1968) asked the question, "What is the point of a nurse's becoming a theorist?" (p. 415). This question is of significance from a tourism perspective; theory is relevant to tourism industry practice, but practice is also relevant to theory. Thus, tourism theory, tourism practice, and tourism research are mutually interrelated and interdependent (Leiper \& Hawker, 2004). Theory is born in practice, refined in research, and returned to practice. This aligns with Aristotle (Nonini, 2016), who held that there were three basic activities of theoria (thinking), poesis (making), and praxis (doing). In this context, theory is the truth, the poetical is the production, and the practical is the action. Praxis here refers to the act of engaging, applying, exercising, realizing, or practicing ideas.

Thus, the contribution of this article to practitioners and industry is in identifying the core drivers of change, how these will impact upon food festivals, and how industry can utilize this information to develop appropriate responses from a strategic perspective. For the academic community, this article provides a conceptual model for the framing of food festival futures that links success to the external environment. Thus, the article attempts to address how practice is based on theory and theory evolves from practice (Leiper \& Hawker, 2004).

\section{Pragmatism and Future Studies}

According to Piirainen and Gonzalez (2015):

For pragmatism, it is the action that enables knowledge. Accordingly, the weight of knowledge claims in pragmatism is typically placed on utility; following knowledge claims in pragmatism is typically placed on utility; following James (1907), a logical claim is valid if (1) acting upon it has the consequence which can be reasonability extrapolated 
from the corresponding logical sentence, and (2) the consequences prove to be useful in practice. In context of foresight this would mean that if a (new) method is useful in producing intended outputs, it is valid, or, if the outputs of a foresight program bring about an intended action, then it has been a useful exercise and the results are valid. Thus in pragmatism, knowledge ... is embodied in the artificial ... and the instantiation of knowledge, how it informs the researcher. (p. 195)

Pragmatism focuses on success through understanding practice (Korte \& Mercurio, 2017). Pragmatism frames and explains activities that continually perform, produce, and reproduce through the dynamics of action, politics, communities, tools, and agents. Thus, pragmatism is a framework to explain success and why something works in a particular way. It is also a bridge between theory and practice. Fundamentally, pragmatism focuses on the practical consequences of what we do and think. It is based on beliefs and actions.

The words "pragmatism," "practice," and "practical" derive from the Greek word for action (Bernstein, 2008). Early pragmatists were concerned with developing actionable knowledge that was useful to people living their everyday lives. Thus, knowing why something was successful is at the heart of pragmatism. Dewey (1905) sought to promote pragmatism by reorienting philosophy away from abstract concerns and turning it instead to an emphasis on human experience. Therefore, at the heart of pragmatism is sources of belief and meanings of actions. These two variables are connected and iterate between each other (D. L. Morgan, 2014), as beliefs must be interpreted as to generate actions, and actions must be interpreted as to generate beliefs, and so forth.

Additionally, pragmatism has a metaphysical implication (Rosiek, 2013). From a futures perspective, it is about understanding the value of consequences and time. It contends the universe is not finished or complete. James (1902) noted that it was "in the making" or "in the process of coming" (p. 29).

Pragmatism collapses the subject/object and the knowledge/value into a single ontological category of experience (Hoch, 2016). This means focusing on the experiences of the practitioner. In the case of WOAP, the practitioners are the experts and stakeholders who are close to food tourism and/or WOAP, who know the discourses, stories, connections, and language of food, but who can also see the bigger picture.

\section{Pragmatism and the Context of This Study}

Time is a key feature of pragmatism, and scenario planning interventions are a form of temporal inquiry that is based on a specific location, constrained by time, and performed for a specific purpose (Yeoman \& McMahon-Beattie, 2016). This intervention and research project was in real time, and the outcome had to be practical and of benefit to WCET. The members of the WCET board are influential leaders of Wellington's tourism and hospitality industries; they are political leaders or those involved in marketing and the food industry. These individuals wanted practical results and did not want to get into an academic debate about the philosophy of food tourism. As Bradfield (2008) and Bradfield et al. (2005) concluded in relation to pragmatic paradigm interventions, they cannot bypass experiences and values, as the intervention usually has political consequences, and there is a pressing need to finish an intervention by bringing about closure.

\section{Research Methodology}

\section{The Project}

The first stage of the research project was the establishment of boundaries, research project aims, and objectives. Access to WOAP documentation was critical, as was an understanding WOAP expectations and agreeing on timelines. Meetings with key actors and stakeholders were scheduled, during which political and power issues that might occur during the process were discussed, and expectations and research gaps established (Van der Heijden et al., 2002). These face-to-face encounters are very important to establish trust and shared expectations in the research process.

\section{Driver Exploration}

This stage involved the identification of the appropriate drivers of change to establish what 


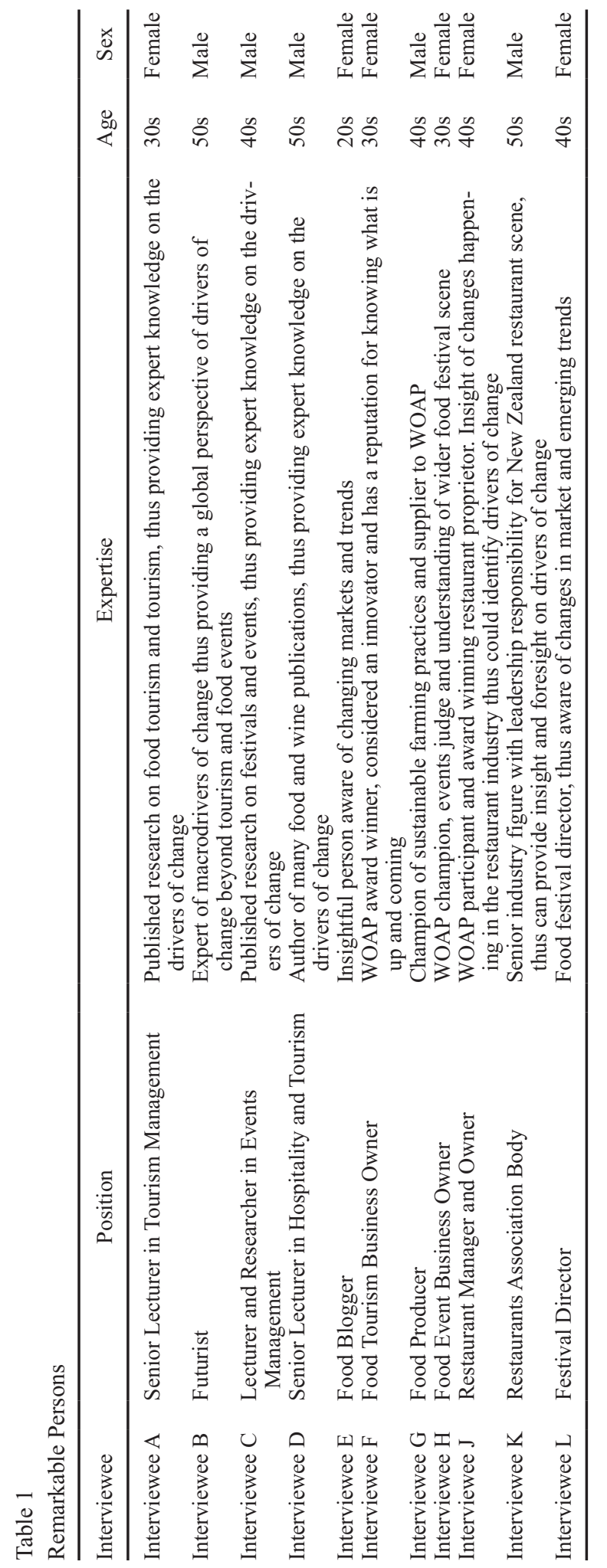


trends to research. As such, an initial literature search was carried out using a STEEP (Social, Technological, Economic, Ecological, and Political) analysis. The next stage involved the identification of remarkable people to explore drivers and to understand the impact of change and possible futures. A remarkable person is a creative and imaginative person who can provide ideas about the area being researched; they are not essentially a specialist in the area that is under investigation, but have some form of knowledge of the topic and can provide and generate new ideas. The role of the remarkable person is to add to the conversation on the topic, as well as to challenge the thinking of the scenario team to help them generate new ideas (Van der Heijden et al., 2002). They should be able to bring in ideas about the future that are beyond the research team's current horizon of thought. In this study, a diverse range of remarkable peoplebusiness and academic experts - were chosen from a long list of 20 people. The research team identified three types of remarkable persons that would be required: those with an understanding of food tourism and festivals; experts in megatrends; and WCET stakeholders who would understand the virtues of the project, and be accessible and knowledgeable. From the long list, 12 remarkable persons agreed to participate in the project (see Table 1).

\section{Interview Process}

The remarkable persons were interviewed with focused questions based on the person's expertise. The questions acted as guides for the interviewers, as the interviews were semistructured. Questions were often open ended, and probes were used to sharpen, improve, clarify, and explore remarkable persons' responses (Easterby-Smith et al., 2008). Questions where clustered into four themes: megadrivers of change, drivers of food tourism, drivers of events and festivals, implications for WAOP and WCET.

The purpose of each interview was to summarize, record, and identify four to six drivers. The questions for each interview (based on the expertise of the remarkable person) were prepared in advance by the project team, and each interview lasted between 50 and $90 \mathrm{~min}$. They were digitally recorded with the permission of the remarkable person. Each interview consisted of two project team members, with one member acting as interviewer and taking responsibility for the questions, and the other member taking notes, highlighting key quotes, and identifying important and recurring themes.

\section{Drivers Workshop}

The purpose of the workshop was to establish the key megadrivers of change. All of the drivers from the interviews were identified prior to the workshop and written up on Post-It notes. A total of 84 driving forces were identified initially. In its process, the workshop followed the principles adopted by Pierre Wack at Shell (Chermack \& Coons, 2015), who ran workshops as back-of-house activities for organizational teams. The first task was to delete any duplication of the driving forces identified by matching Post-It notes for overlap. This was a subjective judgment, based on the expertise of the research team. The Post-It notes were then clustered into matching themes, summarized into 20-30 words, and given a name.

\section{Satisficing-The Council of Elders}

As this research was led by the project team in the form of a back of house operation, the credibility of the output needed to be checked and challenged for robustness. From a pragmatism and scenario planning methodology perspective, the term satisficing is used, which entails searching for an answer that is acceptable and purposeful given the constraint of time (Ackoff, 1978). To achieve this, the board of WOAP acted as a council of elders to whom the project team presented their findings and interpretations. A council of elders approach surfaces assumptions, challenges these, and discusses the plausibility of the identified drivers. The use of the council of elders was a sense-making cognitive heuristic used to establish trustworthiness and plausibility of outcomes (Yeoman et al., 2005). The board at WOAP comprised seven senior leaders from public policy and the tourism, food, and marketing industries, who, combined, represented over 240 years of industry and leadership knowledge and wisdom. Other futures studies have used a council of elders effectively. For example, 
Swanson and Hosier's (2014) Delphi study of the next 40 years of tourism utilized a panel of elderly and experienced persons (known as sages) to draw out insights about megatrends and practices in tourism. Swanson and Hosier argued that the experience of the sages used in the study gave the results utility value and credibility.

A council of elders approach was undertaken twice during the project. Firstly, it was used at an interim stage, when the drivers where identified. On the second occasion, it was used to test the linkage between Yeoman's (2015) model of food tourism and the megadrivers of change and their subsequent implications. For a more comprehensive discussion on scenario planning and drivers workshops, read Scenario Planning: A Field Guide to the Future (Wade, 2012) or Sixth Sense (Van der Heijden et al., 2002).

\section{Megadrivers of Change}

\section{Driver 1: Fluid Identity}

Rising incomes and wealth accumulation distributed in new ways alter the balance of power in tourism. Through the opaqueness of online booking systems for travel and holidays, the power base has shifted from the institution of the travel agent to the individual tourist. At the same time, modern life is rich with new forms of connection and association, allowing a liberated pursuit of personal identity that is fluid and much less restricted by the influence of one's background or geography. Today's society of networks, in turn, has facilitated and innovated a mass of options provided by communication channels leading to the paradox of choice; consumers simply have so much choice of festivals and events (Yeoman, 2016; Yeoman, Robertson, \& Smith, 2012). The concept of fluid identity is supported by Boztug et al.'s (2015) research on the hybrid tourist who challenges the concept of market segmentation. The hybrid consumer buys cheaper generic and low-end brands but trades up on some occasions. She/he likes to sample and try new experiences and has no brand preference (Ehrnrooth \& Gronroos, 2013; Silverstein \& Fiske, 2003). Boztug et al. (2015) emphasized that the hybrid tourist's purchases vary dramatically. She/he wants variety and new experiences, and tends to sample experiences. This is supported in what interviewee E commented:

Although foodies are an important segment, we really cater for the general public, wanting entertainment and variety.

\section{Driver 2: The Role of Science in Food Production}

Interviewee I noted that:

Based upon current trends, the food industry is becoming more competitive and, in the future, we may not have enough food to feed the world as world population is expected to reach 10 billion by 2050 .

If this is the case, alternative sources of food production will need to be adopted-for example, in vitro meat production in laboratories, insect farms for entomophagy consumption, or vertical farms in urban centers (Findlay \& Yeoman, 2015; van Huis et al., 2013). Genetically modified organisms (GMOs) are also a mechanism to feed future populations (Weirich, 2007; Yeoman, 2012a). Thus, considering the impact of climate change, the scarcity of water, and increasing populations, there may well be a dramatic shift from traditional food production systems to innovative, scientifically engineered solutions (Yeoman, 2012a). Interviewee I further noted that:

All this science is innovation. Food and science have always gone together. Whether it was the invention of fertilizer, good husbandry, or in vitro hamburgers.

Furthermore, the role of science in food production has been transferred to the domestic kitchen, with the introduction of home sous-vide machines and other devices (Baldwin, 2012), and chefs such as Heston Blumenthal have raised the popularity of molecular gastronomy (Yeoman \& McMahonBeattie, 2015a).

\section{Driver 3: Urban Society and Population Density}

As the world's population grows, this will result in $90 \%$ of the world's population living in urbanized areas in 44 countries, including most Latin American and many European countries (Danielmeier \& 
Albrecht, 2015; Population Council, 2013; Yeoman et al., 2011). This growth is based on 2.3 million people migrating into developed economies every year (both legal and illegal), accounting for one third of urban growth in the developed world (Population Council, 2013). The future will see a decrease in the availability of land, and there will be increased competition for what land is left available (Tadesse et al., 2014). As urbanization increases, it is envisaged that people will move further away from nature in their daily lives. Thus, from a food tourism perspective, space, hinterland, and the natural environment becomes a desire and a motivation (Yeoman, 2016). Indeed, from a food tourism perspective, as Interviewee L said:

Consumers in an urban society want real food, something that is local and authentic .... it's a reconnection between rural and urban.

\section{Driver 4: The Rebalancing of Global Power}

The rebalancing of global power without doubt has created a shift. Asia's share of the total global economy is rising, and rapidly developing countries (often labeled emerging economies) are expected to see their economic as well as geopolitical influence rise. This will have serious implications for the globalization process and for well-established multinational companies, emerging market competitors, and tourism. China remains on a path to overtake the US as the world's largest economic power within a generation, and India will join both as a global leader by midcentury (Yeoman, 2012a). According to a study by PWC (Hawksworth \& Audino, 2017):

We project that the world economy will roughly double in size by 2042 , growing at an annual average rate of around $2.6 \%$ between 2016 and 2050 . We expect this growth to be driven largely by emerging market and developing countries, with the E7 economies of Brazil, China, India, Indonesia, Mexico, Russia and Turkey growing at an annual average rate of almost $3.5 \%$ over the next 34 years, compared to just $1.6 \%$ for the advanced G7 nations of Canada, France, Germany, Italy, Japan, the UK and the US. (p. 4)

Asia already accounts for over half of the global population, but less than a third of consumer expenditure (Čèsnienė, 2017). Given the vast potential in terms of income growth, Asia is set to become the backbone of consumer markets, with an expected $50 \%$ of global consumer expenditure coming from Asia by 2050. Consistently rising income levels and an increasing number of high-income households will facilitate strong growth in luxury goods in Asia Pacific. Asia is already the biggest and most lucrative luxury goods market and will become even more important in the coming 5 years due to the rising trend of premiumization. This driver was noted by Interviewee $\mathrm{B}$, who stated:

The tourist has changed, with China and other Asian countries the most prominent in recent years. It's not just international visitors, but we are travelling further, tasting new cuisines, and expanding our cultural horizons. Kiwis (New Zealanders) are more liberal, cultured, and open to a fusion of different ideas. WOAP is like that, whether it is making Dumplings or Mr. Go's awardwinning Kiwi-China Burger [https://www.stuff. co.nz/life-style/food-wine/food-news/96360524/ wellingtons-top-burger-dish-and-cocktail].

Also reflecting this trend, Interviewee B noted:

New Zealand is not a France or Italy when it comes to food that represents us. Yes we have Maori cuisine, but that isn't mainstream as isn't accessible to Joe Public. Rather, food in New Zealand is international. A blend of shifting global powers, migration to New Zealand from Asian countries.... Our food is no longer just British or European but a fusion from Asia to the USA.

\section{Driver 5: Mobility}

The phenomenal rise of international travel from 25 million international arrivals in 1950 to over 1 billion today is due to a certain extent to the barriers of mobility having been reduced. Travel is much easier these days, with more direct flights between destinations, visa free entry facilitates, less bureaucratic entry, and immigration taking place on a larger scale (Yeoman, 2012a). As Hall (2015) concluded:

The growth of tourism-related mobility is related to a number of factors including overall increases in global population, urbanisation and the diffusion of a consumer culture that values travelrelated consumption. ... Tourism ... also serves 
to reinforce urbanisation processes and consumer cultures. Tourism is deeply embedded within contemporary neoliberal globalisation and the integration of economic capital with social and mobility capital.” (pp. 1-2)

In terms of tourism mobility, the action of travel may be not only to serve a purpose but also to act as an integral feature of many tourists' experiential demands, including food. The emergence of food as a leisure activity, as well as motivation to travel, results in food as an enabler of travel. In order to sustain mobility, food tourism has created an imaginary of trails and food ways, according to Scott and Duncan (2015), as food has moved from a focus on leisure to an embodied search for belongingness. Interviewee A highlighted this link between tourism and mobility:

The festival (WOAP) is more accessible from a global perspective, reaching out beyond Wellington and to Australia. The programme represents New Zealand and world food ... different cultures and ethnicities [and it] creates a sense of belonging between spaces.

Indeed, Laing and Frost (2015) used the term the food explorer to describe a fan individual who is keen to experience food and wine that is authentic to a region or destination and who is keen to learn about different styles, traditions, and heritage.

\section{Driver 6: Redefining Luxury}

The language of traditional luxury now pervades the commercial mainstream. Every day, common brands invite millions to indulge, upgrade, and enjoy premium tastes and exclusive experiences; indeed, almost every consumer-facing sector, from fast-moving consumer goods (FMCG) to consumer electronics, now borrows from the high-end lexicon (Yeoman \& McMahon-Beattie, 2018). As such, the meaning of luxury is changing. Previously it was associated with materialistic goods, made only for the rich in society and unaffordable for many. With the growth of the middle classes, luxury has become accessible and democratized. As such, luxury has been transformed and can be seen to be associated with conspicuous consumption (Kastanakis \& Balabanis, 2012) — that is, the buying of expensive items to display wealth, status, and income. However, luxury also has a double-edged face of both light and excess and can result in internal and external gratification. On one hand, it is associated with materialism, status, and showing off designer brands; on the other it is internal and inconspicuous, with a focus on experiences, enlightenment, and achievement (Yeoman, 2008). Within the travel sector, luxury is no longer about price or material goods but increasingly about experiences and other intangibles. These include the experience of time, space, authenticity, community individuality, and well-being. All of these are dimensions of luxury that are beyond materialism. Indeed, luxury has moved away from being an exclusive product or service and has become reachable and accessible for the rising middle classes in society.

As Interviewee $\mathrm{H}$ commented:

WOAP represents a range of experiences, some accessible to all and some exclusive. The exclusive events tend to focus on foodies and are premium priced.

\section{Driver 7: Quality of Labor and Capacity}

Academic research on the tourism workforce highlights its complexity and the specific issues it faces in terms of its structure and characteristics, that is, lower pay, lower skill, and unfavorable working hours and conditions (Petersen, 2017). Tourism workforce research is often neglected, and this stems from the challenging characteristics mentioned above, creating a sense of the industry having "no obvious solutions" (Baum et al., 2016; Solnet et al., 2016). Regardless of these issues, the tourism sector represents the largest employer globally (Solnet et al., 2016; Yeoman, 2008), though Getz and Carlsen (2005) highlighted that many tourism businesses are small to medium enterprises, and many owners and operators often have no formal business training or experience. Interviewee B highlighted this, noting:

Today the restaurant industry faces capacity issues due to skill shortages. In the future, the industry will face capacity limits due to the lack of skilled staff wanting to make a career in our industry. Fundamentally, workers are not paid enough, and we must compete with retail and health care for low 
skill workers. The type of industry we are, we place excessive demands on staff and get it wrong.

\section{Driver 8: Stakeholder Engagement and Collaboration}

Collaboration can be used effectively to resolve conflict or advance shared visions, where stakeholders recognize the potential advantages of working together. It is a process of joint decision making among key stakeholders of a problem domain about the future of that domain (Jamal \& Stronza, 2009). In relation to WOAP Interview E commented that:

WOAP brings a sense of belonging and togetherness. For instance, it fosters a closer relationship between suppliers in the food industry and other industries, e.g. chefs and gardeners.

Notably, Interviewee J stated:

Collaboration with the food industry is what makes a food festival successful.

Yeoman (2016) has noted that food tourism is a visionary state, akin to a utopia, that binds stakeholders, communities, and tourists together. Food tourism has political capital, as it is built around a discourse of identity, place, and cultural heritage. As such, it is easy to see why political leaders become involved in food tourism. "Foodies" are the creative class, and communities are the activists. As such, food tourism draws leaders and communities together. It represents a complete system composed of producers, distributors, retailers, and consumers.

\section{Driver 9: Authenticity}

As global consumers continue to embrace the convenience and reliability delivered by mass production, they also aspire to an alternative to the perceived "homogenization" of contemporary culture, food, and leisure experiences (Yeoman, McMahonBeattie, Backer, et al., 2014). In line with this authenticity seekers search for experiences that are real and original, not contaminated by being fake or impure (Yeoman, Brass, et al., 2007). Laing and Frost (2015) note that modern holidaymakers wish to experience cultures and to sample foods and leisure activities to a region or country. Authenticity in relation to food is about products that are simple, rooted in the region, natural, and ethically produced (Yeoman, 2008). Interviewee G identified this driver, stating:

Consumers have a growing desire to search for real experiences through original and natural foods rather than products that are manufactured.

Interviewee $\mathrm{F}$ also noted:

People explore authenticity through going back to basics including learning to cook authentic Thai cuisines with authentic ingredients. Cookery classes stimulate the palette and mind.

Interviewee D commented:

Tourists seek authentic experiences in food. They are searching for deeper and more meaningful experiences.

\section{Driver 10: Experience Economy}

Consumerism is fueled by society's desire to accumulate more goods and services. However, increased access to those products once seen as luxuries has encouraged many to place a greater focus on the pursuit of experiences, whether in addition to, or in place of, more material-based forms of consumption. Food plays an important role in the emerging experience economy, in its preparation, knowledge, and consumption (Laing \& Frost, 2015; Yeoman \& McMahon-Beatte, 2016). Interviewee I said:

It's about teaching and learning about food. It's about hands on experiences and interaction.

Laing and Frost (2015) put the experience economy at the center of tourism for food explorers; food explorers' prime focus and motivation for travel is food and beverages. The hallmark of these tourists is that they want surprises, have a strong interest in experiencing food and wine that is authentic to the destination, and are concerned with sustainability.

\section{Driver 11: Technology Immersion}

In 2050, the world will be even more shaped by technology than it is today (Yeoman, 2012a). 
Currently, countless marketing campaigns and commercial offers promise the consumer an immersive, engaging experience. Retailers, out-of-home leisure providers, video game developers, media creators, and sports broadcasters now borrow from the immersion lexicon in a bid to entice, amaze, and engage consumers one-on-one (Tussyadiah et al., 2018). However, the tools of immersion building are daily being sharpened by relentless technological innovation. New products, such as virtual reality headsets and holographic interfaces, collectively hint at a future where real-life experiences can be convincingly imitated in digital code. Such innovations can magically transport users into specially crafted spaces where they can suspend their disbelief with such ease that they genuinely believe that they are actively present in the faux moment. Indeed, these technologies are allowing tourists to experience destinations before arrival as they enhance the gaze and imagination (Cole \& Razak, 2009). Interviewee A noted that:

Next-generation immersion holds potentially disruptive implications for many areas of life: for how we learn, design, communicate, preview purchase. The possibilities are endless.

Robertson and Brown (2015) argued that technological immersion of festival and event goers is achieved by the stimulation of the five senses; thus, the primary function of the event designer is to manage a holistic perspective of immersion. The use of holograms, fog screens, water screens, data goggles, 3D contact lens, and much more will enhance visual experiences by providing data, images, alerts, explanations, subliminal messages, and signals to motivate action and modify behavior.

\section{Driver 12: Food Security and Safety}

Food security refers to the availability of food and one's access to it. It exists when all people, at all times, have physical, social, and economic access to sufficient, safe, and nutritious food to meet their dietary needs and food preferences for an active and healthy life (Findlay \& Yeoman, 2015; Yeoman, 2012a). Food insecurity will mean a period of pronounced turbulence. Evans (2009) predicted an increased prevalence of shocks, sudden onset crises such as extreme weather events driven by climate change, or spikes in energy prices. Slower onset impacts (stresses) exist, such as land degradation or gradual price inflation, are risks often overlooked by short-term policy or investment planning. Risks also stem from human action through ignorance or accident and from malicious attacks on the food system by terrorists or insurgent groups. Parasecoli (2017) effectively summarises current food security concerns from a social justice perspective:

A variety of factors beginning in the 1970s have played a role in the inception of the new prominence of all things food: growing concerns about the environment, sustainability, and resilience, heightened by the awareness of climate change; the embrace of alternative food production and consumption modes, from the "back to the land movement" to macrobiotics in the counterculture of the 1970s to today's farmers' markets and community-supported agriculture organizations; preoccupations with personal health and nutrition, experienced as closely connected with what we eat; greater visibility in all kinds of media, and especially in social networks, from blogs to Instagram; the prevalence of the so-called experience economy in post-industrial society, where consumers want more than just products; a desire to break free from the mass-produced industrial food managed by big business and the desire for more embedded food production; and the acknowledgement that food availability and accessibility, as well as individual and communal food security, are key components of the struggle toward social justice. (p. 183)

The implications for WOAP can be all summed by this quote from Interviewee $\mathrm{F}$ :

These fears of the consumer have seen them create a discourse of authenticity, simplicity, and sustainability, [and] thus a desire to return to nature. This is where farmer's markets, fresh produce, and provenance have come to prominence, all the virtues of Wellington on a Plate and the values it stands for. A sort of anti-corporation and anticapitalist bohemianism.

\section{Driver 13: Foodies and Serious Leisure}

Food is a hot topic that is constantly in the media and part of popular culture. The visibility of male celebrity chefs, along with books, magazines, and blogs about cooking, seem to indicate, according to 
Cairns et al. (2010), growing enthusiasm for cooking. Consumers want to know about the food they are eating and are genuinely interested in cooking food. Indeed, food can be classed as mainstream experience (Yeoman \& McMahon-Beattie, 2015a). One of the consequences of an educated society is the rise of food as a hobby. Today, tourists differentiate themselves with what they do rather than what they buy (Yeoman, McMahon-Beattie, \& Wheatley, 2015). Supporting this, Getz et al. (2014) have noted that that modern consumer tends to be passionate about specific activities, whether that be playing a sport, being an artist, or being a wine or food connoisseur. Increasingly, they like to "try out" something new, take risks, and be adventurous. Indeed, Yeoman (2015a) noted that food has become a serious leisure activity. Consumers have become interested in acquiring basic cooking skills, hence the rise in cooking and baking classes (Cairns et al., 2010). Interviewee B highlighted this driver stating:

Wellington on a Plate is a foodie's paradise, whether it is making sausages at Preston's the Butcher [https://thespinoff.co.nz/society/wellington-ona-plate/06-06-2017/the-10-most-memorablemoments-in-wellington-on-a-plate-history/] or having dinner at Rimutaka Prison [https://www. visawoap.com/blog/9/dining-behind-bars].

Interviewee $\mathrm{A}$ also commented that:

Wellington on a Plate is your chance to be MasterChef.

\section{Driver 14: Social Capital}

Social capital is the expected collective or economic benefit derived from the preferential treatment and cooperation between individuals and groups (Bourdieu, 1993, 2000). Previously the purchasing aspirations of millions of consumers were molded by the notion that the ownership of expensive material possessions inferred high social status. Socially mobile consumers were continuously invited to own more, whether that was a sports car, a designer watch, limited edition aftershave, or vintage champagne. However, this proposition has been facing a significant challenge for some time now (Yeoman \& McMahon-Beattie, 2015b).
Many consumers still find capital in the ownership of the latest luxury item or experience, but for many flaunting one's material possessions has lost much of the attraction it once had. Food and cooking as social capital can be seen as a representation of Bourdieu's forms of capital that reveal the dynamics of power relations in social life (Sato et al., 2016), with food being a metaphor for social class divisions. Social capital is often associated with socially valued forms of art, music, fashion, and indeed cuisine. Indeed, food can be the ultimate luxury experience, particularly with increased pressure on land due to population growth. Reflecting this driver, Interviewee D stated:

Today's consumers parade their skills, accomplishments, and experiences for others to see via social media. It's a sort of status symbol.

Demand is created for the food tourism experience since it supports cultural identification and social status. Accomplishments, talents, and wider interests such as food have become the new form of currency by which degrees of personal success can be measured. For many consumers, cooking can be a way to fulfill core aspirations, such as the achievement of self-actualization and recognition from others (Yeoman \& McMahon-Beattie, 2015b).

\section{Driver 15: Social Demography Changes}

The demographic profile of the world is rapidly changing: life expectancy is rising while mortality rates are decreasing due to improving healthcare provision and rising affluence. However, demographic patterns are not universal. In Europe, the US, and some Asian markets, fertility rates have declined, and populations are rapidly ageing. Ageing societies are challenging age-based assumptions about senior lifestyles and the choices that they make as consumers. No longer are older consumers regarded as retirees with failing mobility; now they are consumers with active lifestyles and money to spend. This is partially a result of increased health in older age, and partially due to the economic necessity of delayed retirement (Yeoman, 2010). Interviewee $\mathrm{H}$ noted:

Today's consumers are constantly searching for reasons to break routines and indulge in 
unscheduled celebration. We are noticing that baby boomers are driving this trend, finding occasions to do new things. ... Wellington on a Plate seems to be for oldies.

\section{Driver 16: Sustainability and Climate Change}

Climate model projections summarized in a report by the IPCC (Intergovernmental Panel on Climate Change, 2014) indicated that during the 21 st century, the global surface temperature is likely to rise further to $0.3-1.7^{\circ} \mathrm{C}$ in the lowest emissions scenarios and $2.6-4.8^{\circ} \mathrm{C}$ in the highest emissions scenario. The cause of this is largely increasing concentrations of greenhouse gasses $(\mathrm{CHG})$ resulting from human activity, such as burning of fossil fuels and deforestation. This process will cause sea levels to rise, change the amount and pattern of precipitation, expand subtropical deserts, and cause melting in the Artic. It will also increase the frequency and intensity of extreme weather events, species extinctions, and changes in agricultural yields. Although it is hard to estimate to what extent climate change will affect daily life, the number of people who are becoming more concerned about the environment is increasing remarkably (Yeoman, 2012b). Yeoman (2008) suggested that the tourist will be more aware of and more interested in the environment. He goes on to note that, in the future, global warming and climate change will shape what tourists can do and where they can go. More generally, people are addressing this issue through changes to their daily lives, and thus sustainable living is at the forefront of many consumers' motivations, behaviors, and attitudes. In relation to WOAP, Interviewee L stated that:

Sustainability and authenticity are important features of Wellington on Plate with restaurants having to source local ingredients if their menu is to feature in Dine Wellington. . . . Sustainability, which was once a choice, has become a hygiene factor.

\section{Driver 17: Scarcity of Resources}

Rising affluence and growing access to resources will continue to alter fundamentally the lifestyles of consumers in developing economies; resources long taken for granted elsewhere in the world are fueling significant changes to behaviors, diets, and expectations. However, according to Yeoman and McMahon-Beattie (2015b), as the demand for resources increases within ever-populous and prosperous emerging markets and as the disruptive impact of climate change on global supply continues, food and energy prices for end-consumers are likely to be driven up. Whether economic growth can be sustained with finite natural resources is one of the most enduring questions in economics. As Krautkraemer (2005) has highlighted, the last two centuries have seen unprecedented growth in the human population and in the economic well-being of a good portion of the world. This growth has been fed by equally unprecedented natural resource consumption and environmental impacts, including conversion of large portions of the natural world to human use, prompting recurring concerns about whether the world's natural resource base can sustain such growth. In terms of tourism, with 4.7 billion tourists predicted to take international holidays in 2050, one questions whether this is sustainable (Yeoman, 2012a). For example, at the time of writing this paper, Cape Town, a city where tourism is a major employer and economic contributor, was on the verge of running out of water (Maxmen, 2018). Tourism is dependent on water, with coastal destination products based on water. Rivers are equally important for tourism, supporting renowned scenic tours in destinations as diverse as the Nile RiverLuxor (Egypt), the Yangtze-Three Gorges Dam (China), or the Danube (Germany, Austria, Hungary). Many forms of tourism are also indirectly dependent on water availability and quality. The growing global golf tourism market is dependent in most destinations on significant turf grass irrigation. Similarly, an increasing number of skiing and winter sports tourism destinations utilize substantial volumes of water for snowmaking to ensure a quality snow product and to expand the tourism season (Gössling et al., 2015). It is no surprise then that Interviewee L noted:

Scarcity of resources means consumers' minds become focused on what we are doing, hence sustainability becomes more important.

Supporting this further Interviewee E said:

We are likely to see uneven distribution of vital resources, and some regions of the world will be more vulnerable than others. We may come to the 
point where we cannot function because something has been lost.

\section{Driver 18: Technology Singularity}

Singularity is the hypothesis that accelerating progress in technology will cause a runaway effect, whereby artificial technology will exceed human intellectual capacity and control, resulting in huge changes to human civilization. From a pragmatic viewpoint, it is the adoption of the technologies, such as Google Glasses, facial recognition, or automation, that brings about a singularity (Yeoman, 2012a). Indeed, the advent of human-level artificial intelligence (AI) is on the horizon. The development of cyborg style humans is the field of futurist Ray Kurzweil (2005). He has forecasted that new types of technology will emerge, such as optical or quantum computers, and he envisages a point where the functionality of the human brain is quantifiable and matched by technology; singularity means being on the verge of robots as humans. Yeoman (2012a) has imagined the future of tourism in which singularity has arrived. The future labor force, from food operatives to hotel receptionists, are androids. Elements of this are already happening. For example, Gibson (2015) profiled the Moley Robotics Chef. This device is able to reproduce the movements of a human chef in order to create a meal from scratch, with the robot learning the movements after they are performed by a human chef, captured on a 3D camera, and uploaded into the computer.

In line with this, Interviewee E commented:

Imagine Wellington on a Plate in 2050, in which an award-winning Chef is a robot programmed for McDonalds.

\section{Driver 19: Educated Society and Food Culture}

Some $58 \%$ of young adults in Organisation for Economic Co-operation and Development (OECD) countries are expected to enter university-level programs over their lifetimes (OECD, 2018), compared to $3.4 \%$ in 1950 . A society that is educated travels further and is more cultured and adventurous. Therefore, an educated society is one of the main drivers of international travel (Yeoman, 2008). As wealth and educational attainment increases, culture becomes more important as the destination driver. Interviewee $\mathrm{F}$ highlighted the role of education and its connection to the growth of interest in food:

Higher education is one of the world's enablers of global tourism. The educated tourist is more discerning and interested in culture. As food is a cultural experience, food tourism has been one of the beneficiaries of this driver.

\section{Driver 20: Wealth and the Middle Classes}

Increased personal prosperity creates a society that is more demanding and sophisticated (Yeoman \& McMahon-Beattie, 2014a). As discretionary incomes and affluence rise in many countries, consumers will be able to afford a greater level of choice in every aspect of their lives, from personal mobility to healthcare and new types of food and drink. Tourism benefits from this wealth creation, raising the travel aspirations of consumers in both developed and emerging economies. Molavi (2017) highlighted that, as the middle classes have grown in emerging markets such as China, South Korea, India, and Asia, they have developed a taste for holidays, with most consumers ranking spending on holidays at or near the top of the list of things they aspire to spend money on. In relation to WOAP, Interviewee $\mathrm{C}$ commented:

Increased prosperity and a successful economy over the last decade have been one the drivers of success for Wellington on a Plate. Basically, consumers have had more disposal income.

\section{Driver 21: Food and Identity}

Identity is about what makes a person stand out through their behavior, belongings, badges, and discourses (Yeoman, 2010). Individualism is the moral stance, ideology, or social outlook that emphasizes the moral worth of the individual. Individualists promote the primacy of one's goals and desires, and so value independence and self-reliance, advocating that the interests of the individual should achieve precedence over the state or a social group. The sociological concepts of culture, identity, and cuisine can be seen to be intertwined. Stringfellow et al. (2013) adopted and applied Bourdieu's (1993) renowned sociological theory of culture 
and taste to food and tourism to identify that taste is an indicator of wider culture in terms of social status and nationality. Furthermore, according to Danielmeier and Albrecht (2015), food may serve as a differentiator as, for example, one can afford a larger amount or better quality food than someone else. More subtle ways in which food is used to distinguish oneself are through the appreciation of unusual food, knowledge about where and how to obtain it, and how to prepare and eat it. Simply put, food has social status and prestige. Significantly, Interviewee $\mathrm{E}$ stated that:

Food is a form of identity. It is what makes us different. For Wellington on a Plate, the festival creates cultural capital in which foodies can identify with. Its gives them a feeling of prestige and belonging. A sense of community and to show off.

\section{Driver 22: Accessibility}

How accessible should tourism be? Should it be an exclusive experience for the wealthy tourist? Should tourism be accessible to all? What is the relationship between the community and the tourist? There is no doubt that tourism is subject to massive growth. Projections made by the World Tourism Organization anticipate a growth to 1.8 billion international arrivals worldwide till 2030 (UNWTO, 2016), with city tourism the fastest growing sector (Postma \& Schmuecker, 2017). This increase is causing conflict between residents, policy makers, and tourists. During the last 12 months, overtourism has become a political driver for city government leaders, as voters speak out against the ill effects of too many tourists (Ferdinand et al., 2017; Postma \& Schmuecker, 2017). Scholars (e.g., L. T. Williams et al., 2015; P. Williams et al., 2007) have argued that festivals and events can only operate if they engage with communities in a positive way that is beyond economic development, focusing on social, environmental, and cultural aspects. Events and festivals with community support avoid alienation. Interviewee $\mathrm{F}$ stated:

Access is always a balance, as this is a commercial event and its sustainable future depends on revenue and volume. On the other hand, one always needs to remember that Wellington on a Plate couldn't operate without a social license from Wellingtonians.

A Conceptual Model of Food Festivals: Linking Success With the External Environment

Pearce (2012) highlighted that conceptual frameworks identify and bind knowledge and form a context to help researchers understand a particular phenomenon and thus make explanatory claims. Essentially, conceptual frameworks are concepts explained in a diagrammatical format; they are not intended to be theories. Yeoman, McMahon-Beattie, and Wheatley (2015) conceptualized the future of food tourism using a drivers of change model clustered around five themes. The model was derived from chapters published in an edited book titled The Future of Food Tourism. Each chapter is represented as a cognitive map, then aggregated into a conceptual model that represents future discourses, actions, and behaviors of food tourism. The themes were: food tourism as political capital; food tourism as a visionary state; what it means to be a foodie; the drive for affluence and exclusivity; and fluid experiences in a postmodernist world. Subsequently, Yeoman (2015) added a sixth driver, sense of community, based on further analysis (see Fig. 1). This model is a drivers-based model of food tourism, and it has been used here to frame and discuss the megadrivers identified in this research within the context of WOAP and its future success.

\section{Food Festivals as Political Capital}

As the experience economy has evolved, political power and discourse have shifted from manufacturing to services and experiences. Events and festivals, as an important sector within tourism, have taken on political capital as they represent community identity, consciousness, and cultural heritage. Tourism in Wellington has an economic value of NZ \$2B (Wellington Regional Economic Development Agency [WREDA], 2017), with events and festivals being the central component of the tourism strategy. WOAP is staged during the last 2 weeks of August, which is midwinter in New Zealand, and, as such, it creates demand during off-season. It is of economic, social, and cultural benefit to the city; therefore, Wellington's political leaders support the 


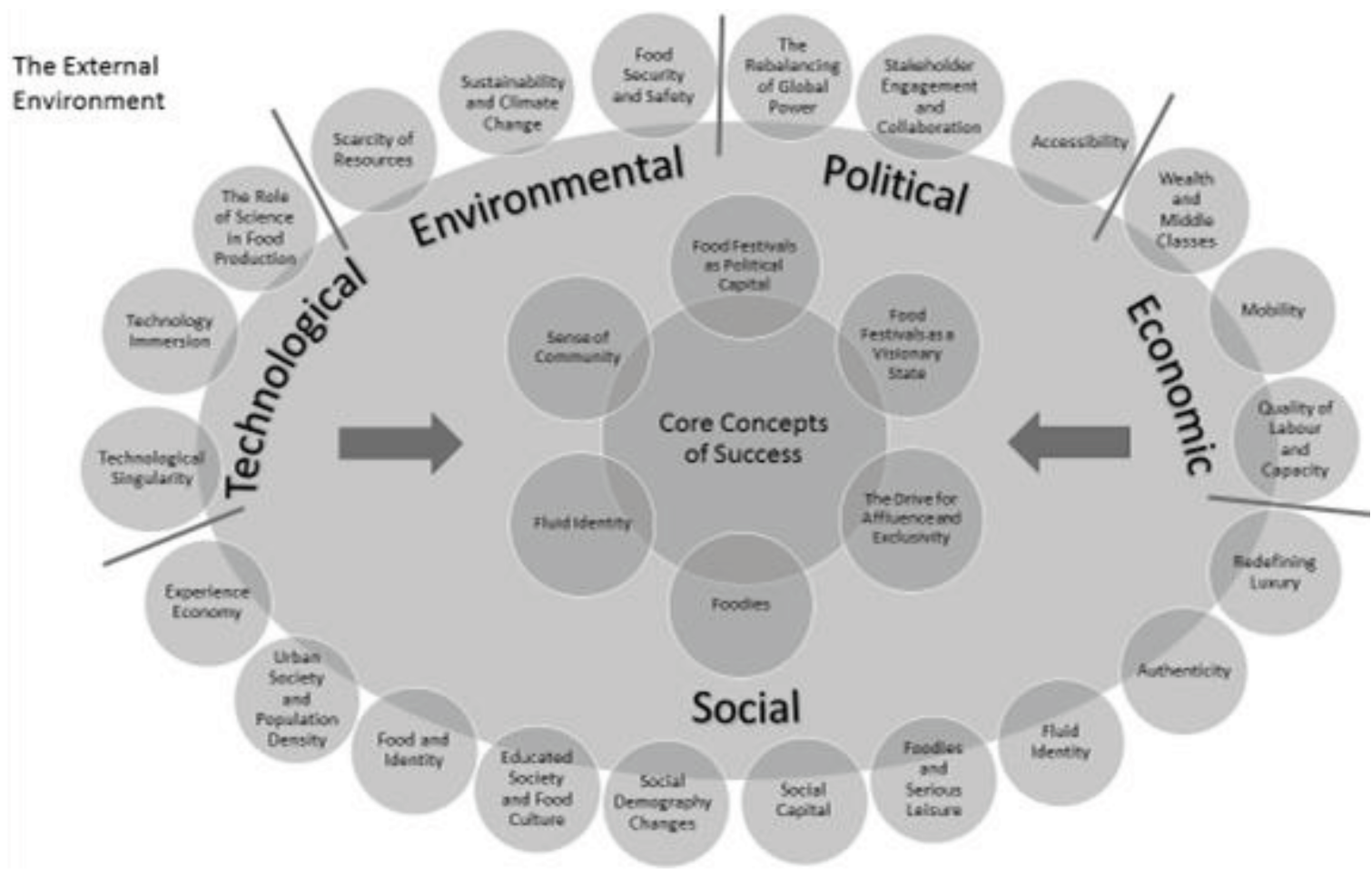

Figure 1. A conceptual model of food festivals: the external environment.

event. Quality of labor and capacity feature as a driver because of the political nature of the problem. It will take political leadership and policy decisions to create a positive outcome that ensures WOAP can grow, and that the city has enough quality chefs, a capable hospitality workforce, and a sufficient food industry base. Stakeholder engagement and collaboration feature because the success of WOAP is due to the cooperation between the various stakeholders. WOAP binds the stakeholders together as a political entity.

\section{Food Festivals as a Visionary State}

Closely linked to the driving force of political capital is that WOAP creates a visionary state. Ideologies are political utopias, paradises, and perfect worlds presented as visions (Bergman et al., 2010). WOAP creates a gaze of authenticity and localism, sustainable menu ingredients, economic development, social responsibility, and community involvement. WAOP is a festival that is the best of everything. It provides indulgent and hedonistic experiences for the creative classes and is an altruistic showcase for organic farmers to sell their products. Drivers featured include Stakeholder engagement and collaboration, as WOAP has the ability bind stakeholders together in a common cause, creating a vision for stakeholders and championing the cause of altruism through sustainability. Authenticity is featured, as WOAP is an alternative to a homogenized food production system, as the focus is on fresh, local, and authentic ingredients. Sustainability and climate change and Scarcity of resources are issues that WOAP is raising awareness of, and Food and identity through WOAP creates an image of Wellington as a food and restaurant city, which are core characteristics of its place brand.

\section{Sense of Community}

Sense of community is the concept that goes beyond structures, formations, and physical location and focuses on the experience of togetherness (Giampiccoli \& Kalis, 2012; Haven-Tang \& 
Jones, 2005; Wise et al., 2017). Urban society and population density gives scale and opportunity, in order that WOAP can take place. With over $60 \%$ of WOAP event goers hailing from the Wellington region, WOAP helps to create both a sense of place and community (Yeoman \& McMahon-Beattie, 2015b). Food security and safety is necessary, as WCET champions good practice throughout the food chain, from farm to fork. For example, in 2017 WOAP hosted a ConversatioNZ symposium (https://www.facebook.com/eatnewzealand/) during the festival to promote, champion, and discuss good food, security, safety, trends, and sustainability. The symposium was rebranded in 2018 as Eat New Zealand (www.eatnewzealand.nz), and it aims to "highlight the quality and vast array of edible resources available in New Zealand." It provides a forum "to encourage and enable collaboration between all levels of the culinary chain and move towards more sustainable food systems."

The purpose of WCET is to create a culinary and hospitality community with WOAP promoting Wellington as New Zealand's culinary capital. This is achieved through stakeholder engagement (Stakeholder engagement and collaboration), as this is seen as the vehicle to champion food tourism, thus creating a sense of community. Many of the drivers represent the values, beliefs, and causes of WOAP and WCET, including Authenticity, Experience economy, Sustainability and climate change, Scarcity of resources, Food and identity, and Accessibility. These represent a common language that binds community stakeholders together.

\section{The Drive for Affluence and Exclusivity}

The political drive to increase the economic value of New Zealand tourism is clear with the ambition to be a $\$ 41 \mathrm{~B}$ industry by 2025 (http://www.tour ism2025.org.nz/). This is reflective of the emphasis on economic development, neoliberalism, industry led strategy, entrepreneurship, and capitalism (Yeoman \& McMahon-Beattie, 2014b). In line with this, the 2025 strategy focuses on affluence and luxury as areas that can make the biggest economic contribution to New Zealand tourism. As food becomes a source of social capital (Social capital), it will also become a more exclusive experience, as luxury providers look for ways to distinguish their products (Redefining luxury). As luxury has become common or democratized (Yeoman \& McMahon-Beattie, 2018), WOAP has developed a number of mechanisms to reinforce exclusivity elements of the festival. For example, price is used to control demand. An example of this is the Bolton Hotel's Martinborough Chef's Tour (https:// www.eventfinda.co.nz/2010/aug/wellington/visawellington-on-plate-bolton-hotel-martinborough) with tickets selling at NZ\$475. Another mechanism is to create unique experiences that consumers consider a "must" purchase, such as the Rimutaka Prison Gate to Plate. Such events create novel, authentic experiences (Authenticity). A focus on craft production is another way to promote exclusivity (Serious leisure and foodies and Authenticity). Finally, WOAP offers the opportunity to become part of an exclusive club, Become a Friend, which allows advance ticket purchase and exclusive offers. Ultimately, WOAP is a commercial venture, with the average price of tickets being $\$ 87$ (personal correspondence with S. Miekle, 2017), thus connecting to the drivers of Wealth and the middle classes, Educated society, Food culture, and The rebalancing of global power.

\section{Fluid Identity}

Event goers want to sample new experiences (Experience economy), and for WOAP, this manifests itself in the variety of events offered. In 2014, for example, the events calendar was divided into the following experience classifications (some of the events overlapped in the terms of classification, hence the percentages add up to $112 \%$ ): $46 \%$ authentic (Authenticity) and craft (Serious leisure and foodies) experiences, 31\% education (Educated society and food culture) and knowledge experiences (The role of science in food production), 23\% indulgence and hedonistic experiences (Fluid identity), and $11 \%$ community-based experiences (Foodies) (Findlay et al., 2014). In 2016, the festival program offered 140 events, with 148 restaurants participating in various promotions (personal correspondence with S. Miekle, 2017). The ultimate sampler event had to be Breakneck Feed, offering 19 dinners and 19 courses in $190 \mathrm{~min}$. Yeoman (2015) pointed out that food tourism experiences offer consumers the ability to differentiate 
themselves; they are luxury to some and a hobby to others. They can combine elements of hedonism and authenticity. Indeed, Yeoman, McMahon-Beattie, and Wheatley (2015) argued that affluent consumers (Wealth and the middle classes) tend to live longer, travel more frequency, and celebrate more often. This results in consumers having a fluid identity with the notions of sampling, novelty, and the urge to try new things. Fluid identity is supported by the drivers of Mobility, Technological immersion, Social capital, Social demography changes, Technological singularity, and Food and identity.

\section{Foodies}

As the experience economy (Experience economy) matures, food festivals and events (Food and identity) have emerged as key experience offerings. The foodie draws upon the drivers of Social capital and Food and identity, as they are part of a network of foodies (Accessibility). That network is associated with expertise, exclusivity (Redefining luxury, wealth and the middle classes), and knowledge (The role of science in food production, Educated society and food culture). The interest in food and the emergence of the 'foodie' is a representation of changing demographics (Social demography changes) and the desire for variety of experiences (Fluid identity, Authenticity) (Findlay \& Yeoman, 2015; Getz et al., 2014; Yeoman, McMahon-Beattie, \& Wheatley, 2015). The driver of Urban society and population density is evidenced in the fact that the WOAP primary event goer is from the Greater Wellington region. The driver Serious leisure and foodies is enshrined in the program, with events such as Baking It Better Mystery Box (https://wellingtonbakehouse.com/2016/08/28/bakingitbetter-awellington-on-a-plate-adventure/), which replicates The Great British Bakeoff (https://thegreatbritishbakeoff.co.uk/). Fundamentally, WOAP is 2 weeks of foodie events.

\section{Contribution}

\section{The Implications for Wellington Culinary Events Trust}

The ultimate success of WCET is measured by the success of the industry players that participate in WOAP, thus bringing economic benefit to the Wellington region. To achieve this, WCET needs to generate a positive vibe about food tourism, the importance of the food culture, food experiences, and good practice in relation to food. In order create a future for WOAP, WCET considered the 22 drivers of change highlighted in this article and the conceptual model of food festival drivers in order to determine what success looks like and how to future proof the festival (Findlay \& Yeoman, 2015; Yeoman, 2015; Yeoman \& McMahon-Beattie, 2015b) and develop a strategic plan. Indeed, the conceptual framework reinforces and clarifies what WCET should be about, that is, "To create world class culinary experiences in Wellington."

To be world class requires the support of the food and restaurant industry in the Wellington region. WOAP provides an opportunity and focus for stakeholders, including farmers, producers, retailers, consumers, and the public and private sector, to work together to create a vision for the future. By creating a vision and emphasizing the benefits, political and community support is achieved. The economic benefit derives from the focus on high value and affluent event goers but is balanced with accessibility for all consumers with events ranging from free to exclusively priced. WOAP is primarily about food; therefore, it has social and cultural status. The festival is for foodies, but more important, the focus is on providing novelty, excitement, and something new. These are the virtues of fluid identity. Thus, the core values of WCET are now Innovation (a recognition of fluid identity and new experiences); Authenticity (delivering an experience that is genuine and real that operates within the virtues sustainable practices); being Anchored in the community (prioritizing stakeholder engagement to create a sense of community of pride and achievement); and Excellence (simply be the best). Overall, these create a framework for the success and future proofing of WOAP.

\section{Theory and Practice of Food Festivals}

At the center of this article is a conceptual framework of the factors associated with food festival success, namely Food festivals as political capital; Food festivals as a visionary state; Sense of community; The drive for affluence and 
exclusivity; and Fluid identity and foodies. The 22 megadrivers detailed in this article provide a comprehensive understanding of the relationships between the external environment and festival success. This conceptualization (as represented in Fig. 1) links many previous studies of internal management success factors (Bornhorst et al., 2010; Fredline, 2003; Lade \& Jackson, 2004; Lemelin et al., 2015; Maxim, 2015) with the external environment. Indeed, researchers had noted that this approach was missing in previous studies (Getz, 2002; Getz et al., 2014; Singh \& Hsiung, 2016). Many food festivals and events have common characteristics and similar issues (Danielmeier \& Albrecht, 2015; Ellis et al., 2018; Getz et al., 2010; Getz et al., 2014; Kinnunen \& Haahti, 2015; Laing \& Frost, 2015; Modlik \& Johnston, 2017; M. J. Morgan, 2015; Robinson et al., 2018; Scott \& Duncan, 2015). As such, generalizable conclusions can be drawn in relation to other food festivals in determining factors of success and strategies for future proofing.

\section{Reflective Thoughts}

\section{Boundaries of Satisficing}

Pragmatic, time-constrained research is by its nature an exercise in satisficing (Herbert, 1991). The stakeholders (WCET, in this case) agreed that the outcomes of the research were purposeful and "satisfactory enough" to meet the aims and objectives of the project. However, from an epistemological perspective, the research results may not be optimal, and the truth may never be known (Festenstein, 2002). Indeed, the research is vulnerable to revision, as others will see something else in the data or approach it from a different perspective. For example, others may identify different megadrivers of change or recommended further clustering. However, the megadrivers reported in this article are those identified by the remarkable persons and verified by WCET as satisfactory within the timeconstrained boundary.

\section{Trustworthiness and Credibility}

A pragmatic paradigm in qualitative research raises the issues of trustworthiness (Decrop, 2004).
What one can say is that the results have credibility. The findings were verified by WCET as purposeful and the remarkable persons as credible, thus confirming the interpretations and findings. The participants throughout the interviews suggested meanings and gave examples. Interviews were cooperative and professional using a range of probing and semistructured questions to draw out experiences and examples. Credibility was also reinforced as two members of the scenario team were present at each remarkable person's interview, one acting as note-taker and the other as interviewer. At the end of each interview, core drivers where identified, and each interview was summarized. Within $24 \mathrm{hr}$ of the interview finishing, each remarkable person was provided with an interview summary and the relevant core drivers drawn from the interview. Within the next $24 \mathrm{hr}$, an email to the remarkable person concerned was followed through to seek verification of the megadrivers and interview summaries.

\section{Conclusion}

The purpose of this research was to help WCET identify which megadrivers of change are important to track in the context of WOAP to compete successfully in the global festival and event environment, thus future proofing the festival. This was achieved through investigating the impact of these drivers of change through Yeoman's (2015) conceptual model of food festival drivers. The article highlights Aristotle's assertion that theory shapes practice and practice shapes theory (Bruell, 2013). This iteration between theory and practice is of importance to tourism research per se, given the vocational nature of the industry. The authors have demonstrated how future studies can be of practical benefit to an organization. The research article makes two contributions. Firstly, it identifies a series of megadrivers of change that food festivals can respond too. Secondly, it conceptualizes a future proofing framework for food festivals to help them attain and maintain success.

\section{References}

Ackoff, R. L. (1978). The art of problem solving. Wiley. Andersson, T. D., \& Getz, D. (2009). Tourism as a mixed industry: Differences between private, public and 
not-for-profit festivals. Tourism Management, 30(6), 847-856. https://doi.org/10.1016/j.tourman.2008.12.008

Anindita, A. G. (2017). A Scenario Planning of the Sharing Economy in Bali Accommodation 2030. [Masters thesis,Victoria University of Wellington]. https:// researcharchive.vuw.ac.nz/xmlui/bitstream/handle/10063/ $6669 /$ thesis_access.pdf? sequence $=1$

Austin, J. E., Gutierrez, R., Ogliastri, E., \& Reficco, E. (2006). Effective management of social enterprises: Lessons from business and civil scoiety organisations in Iberoamerica. Harvard University Press.

Baldwin, D. E. (2012). Sous vide cooking: A review. International Journal of Gastronomy and Food Science, 1(1), 15-30. https://doi.org/10.1016/j.ijgfs.2011.11.002

Baum, T., Kralj, A., Robinson, R. N. S., \& Solnet, D. J. (2016). Tourism workforce research: A review, taxonomy and agenda. Annals of Tourism Research, 60, 1-22. https://doi.org/10.1016/j.annals.2016.04.003

Bélisle, F. J. (1983). Tourism and food production in the Caribbean. Annals of Tourism Research, 10(4), 497-513. doi:10.1016/0160-7383(83)90005-1

Bergman, A., Karlsson, J. C., \& Axelsson, J. (2010). Truth claims and explanatory claims-An ontological typology of futures studies. Futures, 42(8), 857-865. https:// doi.org/10.1016/j.futures.2010.02.003

Bernstein, R. J. (2008). Pragmatism, objectivity, and truth. Philosophical Topics, Pragmatism, 36(1), 19.

Boo, H. C. (2000). Consumer perceptions and concerns about the healthfulness and safety of food served at fairs and festivals. Event Management, 6(2), 85-92. https:// doi.org/10.3727/096020197390167

Bornhorst, T., Ritchie, B. J. R., \& Sheehan, L. (2010). Determinants of tourism success for DMOs \& destinations: An empirical examination of stakeholders' perspectives. Tourism Management, 31(5), 572-589. https://doi. org/10.1016/j.tourman.2009.06.008

Bourdieu, P. (1993). Sociology in question. Sage.

Bourdieu, P. (2000). Distinction: A social critique of the judgement of taste (R. Nice, Trans.). Harvard University Press.

Boztug, Y., Babakhani, N., Laesser, C., \& Dolnicar, S. (2015). The hybrid tourist. Annals of Tourism Research, 54, 190 203. https://doi.org/10.1016/j.annals.2015.07.006

Bradfield, R. (2008). Cognitive barriers in the scenario development process. Advances in Developing Human Resources, 10(2), 198.

Bradfield, R., Wright, G., Burt, G., Cairns, G., \& Van Der Heijden, K. (2005). The origins and evolution of scenario techniques in long range business planning. Futures, 37(8), 795-812. https://doi.org/10.1016/j. futures.2005.01.003

Bruell, C. (2013). Aristotle on theory and practice. In T. L. Pangle \& J. H. Lomax (Eds.), Political philosophy crossexamined: perennial challenges to the philosophic life (pp. 17-28). Palgrave Macmillan.

Bullen, C. V., \& Rockart, J. F. (1986). A primer for critical success factors. In C. V. Bullen \& J. F. Rockart (Eds.), The rise of managerial computing: The best of the center for information system research (pp. 383-423). Dow Jones-Irwin.

Butler, M. W. (1991). Critical success factors revisited: An experiment in their application for information management strategic planning. Victoria University of Wellington.

Cairns, K., Johnston, J., \& Baumann, S. (2010). Caring about food: Doing gender in the foodie kitchen. Gender \& Society, 24(5), 591-615. https://doi.org/ $10.1177 / 0891243210383419$

Čèsnienè, I. (2017). Shifting market frontiers: Asian century. https://go.euromonitor.com/webinar-AsianMarket-2018ShiftingMarketFrontiers_AsianCentury.html

Chang, W. (2011). A taste of tourism: Visitors' motivations to attend a food festival. Event Management, 15(2), 151-161. https://doi.org/10.3727/152599511X1308234 9958190

Chermack, T. J., \& Coons, L. M. (2015). Scenario planning: Pierre Wack's hidden messages. Futures, 73, 187-193. https://doi.org/10.1016/j.futures.2015.08.012

Cole, S., \& Razak, V. (2009). Tourism as future. Futures, 41(8), 335-345. https://doi.org/10.1016/j.futures.2008.11.012

Danielmeier, T., \& Albrecht, J. (2015). Artitecture and future food and wine experiences. In I. Yeoman, U. McMahonBeattie, K. Fields, J. Albrecht, \& K. Meethan (Eds.), The future of food tourism: Foodies, experiences, exclusivity, visions and political capital (pp. 87-100). Channel View.

Decrop, A. (2004). Trustworthiness in qualitative tourism research. In J. Phillimore \& L. Goodson (Eds.), Qualitative research in tourism: ontologies, epistemologies and methodologies (pp. 156-169). Routledge.

Dewey, J. (1905). The realism of pragmatism. The Journal of Philosophy, Psychology and Scientific Methods, 2(12), 324-327. https://doi.org/10.2307/2010861

Dickoff, J., James, P., \& Wiedenbach, E. (1968). Theory in a practice discipline: Part 1: Practice oriented theory. Nursing Research, 17(5), 415-434.

Domenico, R. P. (2001). The regions of Italy: A reference guide to history and culture. Greenwood.

Easterby-Smith, M., Thorpe, R., \& Jackson, P. R. (2008). Management research (3rd ed.). Sage.

Ehrnrooth, H., \& Gronroos, C. (2013). The hybrid consumer: Exploring hybrid consumption behaviour. Management Decision, 51(9), 1793-1820. https://doi.org/10.1108/ MD-12-2012-0867

Einarsen, K., \& Mykletun, R. J. (2009). Exploring the success of the Gladmatfestival (the Stavanger Food Festival). Scandinavian Journal of Hospitality and Tourism, 9(2-3), 225-248. https://doi.org/10.1080/15022250903031550

Ellis, A., Park, E., Kim, S., \& Yeoman, I. (2018). What is food tourism? Tourism Management, 68, 250-263. https://doi.org/10.1016/j.tourman.2018.03.025

Evans, A. (2009). Rising food prices. Chatham House briefing paper. https://reliefweb.int/sites/reliefweb.int/files/ resources/7FBA41E4E121A8284925743B000C5C6EFull_Report.pdf

Everett, S., \& Slocum, S. (2013). Food and tourism: An effective partnership? A UK-based review. Journal of 
Sustainable Tourism, 21(6), 789-809. https://doi.org/10. $1080 / 09669582.2012 .741601$

Feldman, M., \& Worline, M. (2016). The practicality of practice theory. Academy of Management Learning and Education Journal, 15(2), 304-324. https://doi.org/10.5465/ amle.2014.0356

Ferdinand, N., Postma, A., \& White, C. (2017). The future of international events. In N. Ferdinand \& P. J. Kitchin (Eds.), Events management: An international approach (2nd ed., pp. 334-361). Sage.

Festenstein, M. (2002). Pragmatism's boundaries. Millennium - Journal of International Studies, 31(3), 549-571. https://doi.org/10.1177/03058298020310030901

Findlay, K., Goh, S., Nhem, S., Tieng, S., \& Yeoman, I. (2014). 2050: The Future of Food Festivals. Wellington on a Plate seminar presentation, School of Management. Victoria University of Wellington. https://www.victoria. ac.nz/som/about/events/past-events-archived/2050-thefuture-of-food-festivals

Findlay, K., \& Yeoman, I. (2015). Dr Spock's food festival. Journal of Tourism Futures, 1(2), 148-151. https://doi. org/10.1108/JTF-12-2014-0005

Fredline, L. I. Z. (2003). The development of a generic scale to measure the social impacts of events. Event Management, 8(1), 23-37. https://doi.org/10. 3727/152599503108751676

Getz, D. (2002). Why festivals fail. Event Management, 7(4), 209-219. https://doi.org/10.3727/152599502108751604

Getz, D., Andersson, T., \& Carlsen, J. (2010). Festival management studies. International Journal of Event and Festival Management, 1(1), 29-59. doi:10.1108/ 17852951011029298

Getz, D., \& Carlsen, J. (2005). Family business in tourism: State of the art. Annals of Tourism Research, 32(1), 237 258. https://doi.org/10.1016/j.annals.2004.07.006

Getz, D., Robinson, R., Andersson, T., \& Vujicic, S. (2014). Foodies and food tourism. Goodfellow Publishers.

Giampiccoli, A., \& Kalis, J. H. (2012). Tourism, food, and culture: Community-based tourism, local food, and community development in Mpondoland. Culture, Agriculture, Food and Environment, 34(2), 101-123. https://doi. org/10.1111/j.2153-9561.2012.01071.x

Gibson, M. (2015). Meet the robot chef that can prepare your dinner. Time. http://time.com/3819525/robot-chefmoley-robotics/

Gössling, S., Hall, C. M., \& Daniel, S. (2015). Tourism and water. Channel View Publications.

Hall, C. M. (2015). On the mobility of tourism mobilities. Current Issues in Tourism, 18(1), 7-10. https://doi.org/ 10.1080/13683500.2014.971719

Haven-Tang, C., \& Jones, E. (2005). Using local food and drink to differentiate tourism destinations through a sense of place. Journal of Culinary Science \& Technology, 4(4), 69-86. https://doi.org/10.1300/J385v04n04_07

Hawksworth, J., \& Audino, H. (2017). The long view: How will the global economic order change by 2050? https:// www.pwc.com/gx/en/world-2050/assets/pwc-world-in2050-summary-report-feb-2017.pdf
Herbert, S. (1991). Bounded rationality and organizational learning. Organization Science, 2(1), 125-134.

Hoch, C. (2016). Utopia, scenario and plan: A pragmatic integration. Planning Theory, 15(1), 6-22. https://doi. org/10.1177/1473095213518641

Intergovernmantal Panel on Climate Change. (2014). Climate change 2014 synthesis report. https://www.ipcc.ch/ site/assets/uploads/2018/05/SYR_AR5_FINAL_full_ wcover.pdf

Jamal, T., \& Stronza, A. (2009). Collaboration theory and tourism practice in protected areas: Stakeholders, structuring and sustainability. Journal of Sustainable Tourism, 17(2), 169-189. https://doi.org/10.1080/09669580802495741

James, W. (1902). The varieties of religious experience a study in human nature. Longmans, Green, and Co.

James, W. (1907). Pragmatism: A new name for some old ways of thinking (1st ed.). Longmans Green.

Jarzabkowski, P. (2005). Strategy as practice: An activity based approach. SAGE.

Kastanakis, M. N., \& Balabanis, G. (2012). Between the mass and the class: Antecedents of the "bandwagon" luxury consumption behavior. Journal of Business Research, 65(10), 1399-1407. https://doi.org/10.1016/j. jbusres.2011.10.005

Kim, S. (2015). Understanding the historical and geographical contexts of food festival tourism development: The case of the Tatebayashi Noodle Grand Prix in Japan. Tourism Planning \& Development, 12(4), 433-446. doi: 10.1080/21568316.2015.1025991

Kinnunen, M., \& Haahti, A. (2015). Visitor discourses on experiences: Reasons for festival success and failure. International Journal of Event and Festival Management, 6(3), 251-268. https://doi.org/10.1108/IJEFM-012015-0003

Korte, R., \& Mercurio, Z. A. (2017). Pragmatism and human resource development. Human Resource Development Review, 16(1), 60-84. https://doi.org/10.1177/ 1534484317691707

Krautkraemer, J. A. (2005). Economics of natural resource scarcity: The state of the debate. https://ageconsearch. umn.edu/record/10562/.

Kurzweil, R. (2005). The singularity is near: When humans transcend biology. Viking.

Lade, C., \& Jackson, J. (2004). Key success factors in regional festivals: Some Australian experiences. Event Management, 9(1-2), 1-11. https://doi.org/10. $3727 / 1525995042781066$

Laing, J., \& Frost, W. (2015). The new food explorer: Beyond the experience economy. In I. Yeoman, U. McMahon-Beattie, K. Fields, J. Albrecht, \& K. Meetham (Eds.), The future of food tourism: Foodies, experiences, exclusivity, visions and political capital (pp. 177-193). Channel View.

Leiper, N., \& Hawker, M. (2004). The management gap in tourism research and education. Paper presented at the CAUTHE Creating Tourism Knowledge, Brisbane.

Lemelin, R. H., Koster, R., \& Youroukos, N. (2015). Tangible and intangible indicators of successful aboriginal 
tourism initiatives: A case study of two successful aboriginal tourism lodges in Northern Canada. Tourism Management, 47, 318-328. https://doi.org/10.1016/j. tourman.2014.10.011

Lewin, K. (1951). The importance of theory. In D. Cartwright (Ed.), Field theory in social science: Selected theoretical papers (pp. 168-179). Harper \& Row.

Lilleheim, H., Mykletum, R. J., Quain, W. J., \& Engstom, C. (2005). South Beach Wine and Food Festival: Why participate? Hospitality Review, 23(2), 1-12.

Luhmann, N. (1976). The future cannot begin: Temporal structures in modern society. Social Research, 43(1), $130-152$

Mason, M. C., \& Paggiaro, A. (2012). Investigating the role of festivalscape in culinary tourism: The case of food and wine events. Tourism Management, 33(6), 1329-1336. https://doi.org/10.1016/j.tourman.2011.12.016

Maxim, C. (2015). Drivers of success in implementing sustainable tourism policies in urban areas. Tourism Planning \& Development, 12(1), 37-47. https://doi.org/10.1 080/21568316.2014.960599

Maxmen, A. (2018). Cape Town scientists prepare for 'Day Zero'. Nature, 554(7690), 13-14.https://doi.org/10.1038/ d41586-018-01134-x

McDonald, P. (2011). It's time for management version 2.0: Six forces redefining the future of modern management. Futures, 43(8), 797-808. https://doi.org/10.1016/j. futures.2011.05.001

Modlik, M., \& Johnston, L. (2017). Huhu grubs, bull semen shots and koki: Visceral geographies of regional food festivals in Aotearoa. New Zealand Geographer, 73(1), 25-34. https://doi.org/10.1111/nzg. 12148

Molavi, A. (2017, August 23). Decline of the Western tourist. https://foreignpolicy.com/2017/08/23/the-decline-ofthe-western-tourist-china-india/

Morgan, D. L. (2014). Pragmatism as a paradigm for social research. Qualitative Inquiry, 20(8), 1045-1053. https:// doi.org/10.1177/1077800413513733

Morgan, M. J. (2015). Food festivals, food marketing and the re-invention of a rural community. Journal of $\mathrm{New}$ Business Ideas and Trends, 13(2), 57.

Myerscough, J. (1990). The economic importance of the arts in Britain. Museum Management and Curatorship, 9(2), 226-227. https://doi.org/10.1016/0964-7775(90)90072-F

Nonini, D. (2016). Praxis. Dialect Anthropology, 40(3), 241-249.

Organisation for Economic Co-operation and Development. (2018). Education at a Glance 2017. https://www.oecdilibrary.org/docserver/eag-2017-en.pdf?expires $=161308$ $1210 \& \mathrm{id}=\mathrm{id} \&$ accname $=$ guest $\&$ checksum $=\mathrm{DA} 159 \mathrm{E} 7 \mathrm{BF}$ ED9A7BECA95791F7408D0F8

Parasecoli, F. (2017). Global trade, food safety, and the fear of invisible invaders. Social Research, 84(1), 183.

Park, K. S., Reisinger, Y., \& Kang, H. J. (2008). Visitors' motivation for attending the South Beach Wine and Food Festival, Miami Beach, Florida. Journal of Travel \& Tourism Marketing, 25(2), 161-181. https://doi. org $/ 10.1080 / 10548400802402883$
Pearce, D. G. (2012). Frameworks for tourism research CABI.

Petersen, L. (2017). The future of the New Zealand tourism workforce: 2035 [Master of Commerce, Victoria Univesity of Wellington]. http://hdl.handle.net/10063/6802

Piirainen, K. A., \& Gonzalez, R. A. (2015). Theory of and within foresight: "What does a theory of foresight even mean?" Technological Forecasting \& Social Change, 96, 11.

Population Council. (2013). The United Nations 2012 population projections. Population and Development Review, 39(3), 551-555.

Postma, A., \& Schmuecker, D. (2017). Understanding and overcoming negative impacts of tourism in city destinations: Conceptual model and strategic framework. Journal of Tourism Futures, 3(2), 144-156. https://doi. org/10.1108/JTF-04-2017-0022

Postma, A., \& Yeoman, I. (2016). Conceptualising scenario planning in tourism futures: Vignettes of practice. Paper presented at the CAUTHE 2016: The Changing Landscape of Tourism and Hospitality: The Impact of Emerging Markets and Emerging Destinations, Blue Mountains International Hotel School. Sydney. https://search.informit.org/documentSummary; dn=936497265387202;res= IELBUS

Robertson, M., \& Brown, S. (2015). Leadership and visionary futures. In I. Yeoman, M. Robertson, U. McMahonBeattie, E. Backer, \& K. Smith (Eds.), The future of events and festivals (pp. 219-235). Routledge.

Robertson, M., Yeoman, I., Smith, K., \& McMahon-Beattie, U. (2015). Technology, society, and visioning the future of music festivals. Event Management, 19(4), 567-587.

Robinson, R. N. S., Getz, D., \& Dolnicar, S. (2018). Food tourism subsegments: A data-driven analysis. International Journal of Tourism Research, 23(3), 367-377. https://doi.org/10.1002/jtr.2188

Rosiek, J. L. (2013). Pragmatism and post-qualitative futures. International Journal of Qualitative Studies in Education, 26(6), 692-705. https://doi.org/10.1080/095 18398.2013.788758

Saritas, O., \& Smith, J. E. (2011). The big picture: Trends, drivers, wild cards, discontinuities and weak signals. Futures, 43(3), 292-312. https://doi.org/10.1016/j. futures.2010.11.007

Sato, P. M., Gittelsohn, J., Unsain, R. F., Roble, O. J., \& Scagliusi, F. B. (2016). The use of Pierre Bourdieu's distinction concepts in scientific articles studying food and eating: A narrative review. Appetite, 96, 174-186. https:// doi.org/10.1016/j.appet.2015.09.010

Schänzel, H. A., \& Yeoman, I. (2014). The future of family tourism. Tourism Recreation Research, 39(3), 343-360. https://doi.org/10.1080/02508281.2014.11087005

Schatzki, T. R. (1996). Social practices: A Wittgensteinian approach to human activity and the social. Cambridge University Press.

Schatzki, T. R. (2001). Introduction: Practice theory. In K. Cetina \& E. von Savigny (Eds.), The practice turn in contemporary theory (pp. 1-14). Routledge. 
Scott, D., \& Duncan, T. (2015). Back to the future: The affective power of food in reconstructing a tourist imaginary. In I. Yeoman, U. McMahon-Beattie, K. Fields, J. Albrecht, \& K. Meethan (Eds.), The future of food tourism: Foodies, experiences, exclusivity, visions and political capital (pp. 143-156). Channel View.

Silverstein, M., \& Fiske, N. (2003). Trading up: The new American Luxury. Portfolio.

Sims, R. (2009). Food, place and authenticity: Local food and the sustainable tourism experience. Journal of Sustainable Tourism, 17(3), 321-336. https://doi. org/10.1080/09669580802359293

Sims, R. (2010). Putting place on the menu: The negotiation of locality in UK food tourism, from production to consumption. Journal of Rural Studies, 26(2), 105-115. https://doi.org/10.1016/j.jrurstud.2009.09.003

Singh, N., \& Hsiung, Y. (2016). Exploring critical success factors for Napa's wine tourism industry from a demand perspective. Anatolia, 27(4), 433-443. https://doi.org/10. 1080/13032917.2016.1160414

Smith, S., Costello, C., \& Muenchen, R. A. (2010). Influence of push and pull motivations on satisfaction and behavioral intentions within a culinary tourism event. Journal of Quality Assurance in Hospitality \& Tourism, 11(1), 17-35. https://doi.org/10.1080/15280080903520584

Solnet, D., Baum, T., Robinson, R. N. S., \& LockstoneBinney, L. (2016). What about the workers? Roles and skills for employees in hotels of the future. Journal of Vacation Marketing, 22(3), 212-226. https://doi. org/10.1177/1356766715617403

Sparrow, J. (1998). Knowledge in organisations: Access to thinking at work. Sage.

Steiger, R. (2012). Scenarios for skiing tourism in Austria: Integrating demographics with an analysis of climate change. Journal of Sustainable Tourism, 20(6), 867-882. https://doi.org/10.1080/09669582.2012.680464

Stringfellow, L., MacLaren, A., Maclean, M., \& O'Gorman, K. (2013). Conceptualizing taste: Food, culture and celebrities. Tourism Management, 37(Suppl. C), 77-85. https://doi.org/10.1016/j.tourman.2012.12.016

Sundbo, J. (2016). Food scenarios 2025: Drivers of change between global and regional. Futures, 83, 75 .

Swanson, J. R., \& Hosier, A. F. (2014). Tourism sages prognosticate the next 40 years of tourism industry. Tourism Recreation Research, 39(3), 361-378. https://doi.org/10. 1080/02508281.2014.11087006

Tadesse, G., Algieri, B., Kalkuhl, M., \& von Braun, J. (2014). Drivers and triggers of international food price spikes and volatility. Food Policy, 47, 117-128. https:// doi.org/10.1016/j.foodpol.2013.08.014

Tussyadiah, P., Wang, D., Jung, T. H., \& Dieck, C. (2018). Virtual reality, presence, and attitude change: Empirical evidence from tourism. Tourism Management, 66, 140 154. https://doi.org/10.1016/j.tourman.2017.12.003

United Nations World Tourism Organization. (2016). UNWTO tourism highlights, 2016 edition. https://www.eunwto.org/doi/pdf/10.18111/9789284418145 van Huis, A., Van Itterbeeck, J., Klunder, H., Mertens, E., Halloran, A., Muir, G., \& Vantomme, P. (2013). Edible insects: Future prospects for food and feed security. Food and Agriculture Organization of the United Nations. http://www.fao.org/3/i3253e/i3253e00.pdf

Van der Heijden, K., Bradfield, R., Burt, G., Cairns, G., \& Wright, G. (2002). Sixth sense: Accelerating organizational learning with scenarios. Wiley.

van't Klooster, S. A., \& van Asselt, M. B. A. (2006). Practising the scenario-axes technique. Futures, 38(1), 15-30. https://doi.org/10.1016/j.futures.2005.04.019

van Zon, H. (1992). Alternative scenarios for Central Europe. Futures, 24(5), 471-482. https://doi.org/10.1016/00163287(92)90017-A

Wade, W. (2012). Scenario planning: A field guide to the future. Wiley.

Weick, K. E. (1989). Theory construction as disciplined imagination. Academy of Management Review, 14(4), 516-531.

Weirich, P. (Ed.). (2007). Labeling genetically modified food: The philosophical and legal debate. Oxford University Press.

Wigford, A. (2014). Future-proofing for success. International School, 17(1), 41-42.

Williams, L. T., Germov, J., Fuller, S., \& Freij, M. (2015). A taste of ethical consumption at a slow food festival. Appetite, 91(Suppl. C), 321-328. https://doi.org/10.1016/j. appet.2015.04.066

Williams, P., Gill, A., \& Ponsford, I. (2007). Corporate social responsibility at tourism destinations: Toward a social license to operate. Tourism Review International, 11(2), 133-144. https://doi.org/10.3727/154427207783948883

Wise, N., Mulec, I., \& Armenski, T. (2017). Towards a new local tourism economy: Understanding sense of community, social impacts and potential enterprise opportunities in Podgrađe Bač, Vojvodina, Serbia. Local Economy: The Journal of the Local Economy Policy Unit, 32(7), 656-677. https://doi.org/10.1177/0269094217734329

Wellington Regional Economic Development Agency. (2017). WREDA annual report 2016-2017. https:// resources.wellingtonnz.com/products/wreda-annualreport-2016-17

Yeoman, I. (2008). Tomorrow's tourist: Scenarios and trends. Elsevier Science.

Yeoman, I. (2010). Tomorrow's tourist: Fluid and simple identities. Journal of Globalization Studies, 1(2), $118-127$

Yeoman, I. (2012a). 2050: Tomorrow's tourism. Channel View.

Yeoman, I. (2012b). Tourism 2050: Scenarios for New Zealand. Victoria University of Wellington.

Yeoman, I. (2015, April 8-11). The future of food tourism. Paper presented at the World Tourism Summit. Estoril, Portugal.

Yeoman, I. (2016). The future tourist: Fluid and simple identities. Victoria University of Wellington. https://vimeo. com/181103735/ad143522da 
Yeoman, I. (Producer). (2017, March 2017). The future of tourism [Conference Presentation]. https://vimeo.com/ album/4648621/video/222658667

Yeoman, I., Brass, D., \& McMahon-Beattie, U. (2007). Current issue in tourism: The authentic tourist. Tourism Management, 28(4), 1128-1138. https://doi.org/10.1016/j. tourman.2006.09.012

Yeoman, I., Galt, M., \& McMahon-Beattie, U. (2005). A case study of how VisitScotland prepared for war. Journal of Travel Research, 44(1), 6-20.

Yeoman, I., Hsu, C., Smith, K., \& Watson, S. (2011). Tourism and demography. Goodfellows.

Yeoman, I., Lennon, J. J., Blake, A., Galt, M., Greenwood, C., \& McMahon-Beattie, U. (2007). Oil depletion: What does this mean for Scottish tourism? Tourism Management, 28(5), 1354-1365. https://doi.org/10.1016/j. tourman.2006.09.014

Yeoman, I., \& McMahon-Beatte, U. (2016). The future of food tourism. Journal of Tourism Futures, 2(1), 95-98. https://doi.org/10.1108/JTF-12-2015-0051

Yeoman, I., \& McMahon-Beattie, U. (2014a). Exclusivity: The future of luxury. Journal of Revenue and Pricing Management, 13(1), 12-22. https://doi.org/10.1057/rpm.2013.29

Yeoman, I., \& McMahon-Beattie, U. (2014b). New Zealand tourism: Which direction would it take? Tourism Recreation Research, 39(3), 415-435. https://doi.org/10.1080/ 02508281.2014.11087009

Yeoman, I., \& McMahon-Beattie, U. (2015a). The changing demographics of male foodies: Why men cook but don't wash up. In I. Yeoman, U. McMahon-BEattie, K. Fields, J. Albrecht, \& K. Meethan (Eds.), The future of food tourism: Foodies, experiences, exclusivit, visions and political capital (pp. 157-176). Channel View.

Yeoman, I., \& McMahon-Beattie, U. (2015b). The future of food tourism: The Star Trek replicator and exclusivity. In I. Yeoman, McMahon-Beattie, K. Fields, J. Albrecht, \& K. Meethan (Eds.), The future of food tourism: Foodies, experiences, exclusivity, visions and political capital (pp. 23-47). Channel View.
Yeoman, I., \& McMahon-Beattie, U. (2015c). Trends: Cyborg games. Journal of Tourism Futures, 1(1), 74-77. https://doi.org/10.1108/JTF-12-2014-0019

Yeoman, I., \& McMahon-Beattie, U. (2016). An ontological classification of tourism futures. Paper presented at the CAUTHE 2016: The Changing Landscape of Tourism and Hospitality: The Impact of Emerging Markets and Emerging Destinations., Sydney.

Yeoman, I., \& McMahon-Beattie, U. (2018). The future of luxury: Mega drivers, new faces and scenarios. Journal of Revenue and Pricing Management, 17, 2014-217. https://doi.org/10.1057/s41272-018-0140-6

Yeoman, I., McMahon-Beattie, U., Backer, E., Robertson, M., \& Smith, K. (Eds.). (2014). The Future of Events \& Festivals. Routledge.

Yeoman, I., McMahon-Beattie, U., Fields, K., Albrecht, J., \& Meethan, K. (2015). The future of food tourism: foodies, experiences, exclusivity, visions and political capital. Channel View.

Yeoman, I., McMahon-Beattie, U., \& Findlay, K. (2014). The future of urban spas: A trend analysis of the UK market. Tourism Recreation Research, 39(3), 397-413. https://doi.org/10.1080/02508281.2014.11087008

Yeoman, I., McMahon-Beattie, U., \& Wheatley, C. (2015). The future of food tourism: A cognitive map(s) perspective. In I. Yeomaan, U. Mcmahon-Beattie, K. Fields, J. Albrecht, \& K. Meethan (Eds.), The future of food tourism: Foodies, experiences, exclusivity, visions and political capital (pp. 237-278). Channel View.

Yeoman, I., Robertson, M., \& Smith, K. (2012). A futurist's view on the future of events. In S. Page \& J. Connell (Eds.), The Routledge handbook of events (pp. 507-525). Routledge.

Yunn, D., Hennessey, S. M., \& MacDonald, R. (2011). Understanding culinary tourists: Segmentations based on past culinary experiences and attitudes toward foodrelated behaviour. Paper presented at the International CHRIE Conference. https://scholarworks.umass.edu/ refereed/ICHRIE_2011/Friday/15/ 
